\title{
Desirable Traits of a Good Biocontrol Agent against Verticillium Wilt
}

\author{
Silke Deketelaere ${ }^{\ddagger}$, Lien Tyvaert ${ }^{\ddagger}$, Soraya C. França ${ }^{\dagger}$ and Monica Höfte* \\ Laboratory of Phytopathology, Department of Crop Protection, Faculty of Bioscience Engineering, Ghent University, Ghent, \\ Belgium
}

The soil-borne fungus Verticillium causes serious vascular disease in a wide variety of annual crops and woody perennials. Verticillium wilt is notoriously difficult to control by conventional methods, so there is great potential for biocontrol to manage this disease. In this study we aimed to review the research about Verticillium biocontrol to get a better understanding of characteristics that are desirable in a biocontrol agent (BCA) against Verticillium wilt. We only considered studies in which the BCAs were

Edited by:

Jesús Mercado-Blanco, Consejo Superior de Investigaciones

Científicas (CSIC), Spain

Reviewed by:

Sotiris Tjamos,

Agricultural University of Athens,

Greece

Nieves Goicoechea,

Universidad de Navarra, Spain

*Correspondence:

Monica Höfte

Monica.Hofte@ugent.be

${ }^{\dagger}$ Present Address:

Soraya C. França,

$R \& D$ Microbials, Biobest NV, Westerlo,

Belgium

${ }^{\ddagger}$ These authors have contributed equally to this work.

Specialty section:

This article was submitted to

Plant Microbe Interactions,

a section of the journal

Frontiers in Microbiology

Received: 28 April 2017

Accepted: 12 June 2017

Published: 06 July 2017

Citation:

Deketelaere S, Tyvaert L, França SC and Höfte M (2017) Desirable Traits of

a Good Biocontrol Agent against Verticillium Wilt.

Front. Microbiol. 8:1186.

doi: 10.3389/fmicb.2017.01186 tested on plants. Most biocontrol studies were focused on plants of the Solanaceae, Malvaceae, and Brassicaceae and within these families eggplant, cotton, and oilseed rape were the most studied crops. The list of bacterial BCAs with potential against Verticillium was dominated by endophytic Bacillus and Pseudomonas isolates, while non-pathogenic xylem-colonizing Verticillium and Fusarium isolates topped the fungal list. Predominant modes of action involved in biocontrol were inhibition of primary inoculum germination, plant growth promotion, competition and induced resistance. Many BCAs showed in vitro antibiosis and mycoparasitism but these traits were not correlated with activity in vivo and there is no evidence that they play a role in planta. Good BCAs were obtained from soils suppressive to Verticillium wilt, disease suppressive composts, and healthy plants in infested fields. Desirable characteristics in a BCA against Verticillium are the ability to (1) affect the survival or germination of microsclerotia, (2) colonize the xylem and/or cortex and compete with the pathogen for nutrients and/or space, (3) induce resistance responses in the plant and/or (4) promote plant growth. Potential BCAs should be screened in conditions that resemble the field situation to increase the chance of successful use in practice. Furthermore, issues such as large scale production, formulation, preservation conditions, shelf life, and application methods should be considered early in the process of selecting BCAs against Verticillium.

\footnotetext{
Keywords: biocontrol, biological control, cross-protection, endophytes, soil-borne pathogens, survival structures, vascular pathogen, Verticillium wilt
}

\section{INTRODUCTION}

Vascular wilts caused by members of the genus Verticillium are among the most devastating fungal diseases worldwide. The genus Verticillium consists of a relatively small group of soilborne ascomycete fungi and several of them cause wilt disease on a variety of plant hosts in many parts of the world. Causal agents of Verticillium wilt diseases are globally distributed, most prevalent in temperate and subtropical regions and rare in tropical regions. The consequences of 
Verticillium infection can be far-reaching, leading to huge yield losses (Pegg and Brady, 2002). Currently, 10 species are defined within the Verticillium genus (Table 1) of which Verticillium dahliae has the broadest host range and infects over 200 plant species (Inderbitzin et al., 2011; Inderbitzin and Subbarao, 2014). Verticillium species produce long-lasting resting structures such as microsclerotia, chlamydospores, and resting mycelium in dead or dying plant tissues (Table 1). These resting structures serve as the primary inoculum from which hyphae are formed that directly penetrate the roots of host plants. Subsequently, the fungus reaches the vascular tissue and colonizes the xylem vessels (Puhalla and Bell, 1981; Schnathorst, 1981). Symptoms associated with Verticillium wilt are stunting, chlorosis, wilting, vascular discoloration, and early senescence. However, symptoms can differ considerably between hosts (Fradin and Thomma, 2006) and Verticillium species (Figure 1). For example, Verticillium longisporum causes wilting in cauliflower but necrosis on oilseed rape (Depotter et al., 2016). In addition, many plants can harbor endophytic populations of Verticillium without showing any symptoms and should be considered as "asymptomatic hosts" (Malcolm et al., 2013). Moreover, within the different Verticillium species non-pathogenic isolates can be found that do not cause symptoms upon inoculation of host plants. Several of these nonpathogenic Verticillium isolates show biocontrol efficacy against Verticillium wilt (Matta and Garibaldi, 1977; Davis et al., 2000; Robinson et al., 2007; Qin et al., 2008; García et al., 2011; França et al., 2013; Zhu et al., 2013; Tyvaert et al., 2014).

\section{CURRENT CONTROL STRATEGIES FOR VERTICILLIUM WILT}

Control of Verticillium disease is difficult due to the long persistence of the resting structures in the field and the broad host range of some species. Moreover, the pathogen is difficult to manage once it reaches the vascular plant tissue and fungicides appear to be ineffective. Reducing the primary inoculum in the soil has been considered as an important goal and can be accomplished by several management strategies. Chemical fumigants can reduce the inoculum of Verticillium in soil, however their use is restricted because of the detrimental effect on the environment. Disease management has been focusing on implementing integrated pest management (IPM). Different IPM strategies to reduce the primary inoculum were recently summarized by the EIP-AGRI focus group of soil-borne diseases (https://ec.europa.eu/eip/agriculture/en/ content/focus-groups) and include crop rotation, the use of cover crops, green manures, and organic amendments, and non-chemical soil disinfestation (solarization, soil steaming, anaerobic disinfestation, inundation, and biofumigation). Those management strategies have been implemented into agricultural production and all of them have their specific concerns and limitations.

Another interesting approach is the protection of plants against Verticillium by genetic resistance. Resistance has been identified in a limited number of crops and has mainly been studied in tomato, potato and cotton. Grafting on resistant rootstocks is a common strategy to protect vegetables, such as tomato and pepper, against soil-borne pathogens, but is not always effective in controlling Verticillium wilt (Garibaldi et al., 2005; Geboloğlu et al., 2011). Resistance may break down under high disease pressure, leading to new races of the pathogen or a shift in the pathogen population (Lazarovits and Subbarao, 2009; Colla et al., 2012). For example, Verticillium wilt of tomato was effectively controlled by growing cultivars with resistance against $V$. dahliae race 1 (Schaible et al., 1951). Later on, a shift in the pathogen population occurred and race 2 became dominant (Grogan et al., 1979; Dobinson et al., 1996) for which no resistant cultivars are available.

Another tool for IPM is the use of biological control agents (BCAs), a promising strategy to control soil-borne diseases such as Verticillium. Although several microorganisms have shown efficacy against Verticillium wilt, hardly any of them

TABLE 1 | Species within Verticillium with their host range and survival structures.

\begin{tabular}{|c|c|c|}
\hline Species & Host range & Survival structures \\
\hline Verticillium albo-atrum & Pestilence wort, Potato, Stinging nettle & microsclerotia, resting mycelium \\
\hline Verticillium alfalfae & Alfalfa & resting mycelium \\
\hline Verticillium dahliae & wide & microsclerotia \\
\hline Verticillium isaacii & $\begin{array}{l}\text { Artichoke, Bear's breech, Brassica sp., Florist's daisy, Hairy nightshade, Lettuce, } \\
\text { Potato, Spinach, Tomato }\end{array}$ & microsclerotia, resting mycelium, chlamydospores \\
\hline Verticillium klebahnii & Artichoke, Lettuce & microsclerotia, resting mycelium, chlamydospores \\
\hline Verticillium longisporum & $\begin{array}{l}\text { Birdrape, Broccoli, Cabbage, Cauliflower, Field mustard, Horseradish, Oilseed } \\
\text { rape, Sugar beet, Turnip, Wild radish }\end{array}$ & microsclerotia \\
\hline Verticillium nonalfalfae & $\begin{array}{l}\text { Alfalfa, Cotton, Hop, Petunia, Potato, Spinach, Tomato, Tree of heaven, Wild } \\
\text { celery }\end{array}$ & resting mycelium \\
\hline Verticillium nubilum & Potato & chlamydospores \\
\hline Verticillium tricorpus & Carnation, Larkspur, Lettuce, Potato, Tomato & microsclerotia, resting mycellium, chlamydospores \\
\hline Verrticillium zaregamsianum & Tomato, Potato, Lettuce, Ten weeks stock & microsclerotia, resting mycelium \\
\hline
\end{tabular}

Inderbitzin et al., 2011; Inderbitzin and Subbarao, 2014. 

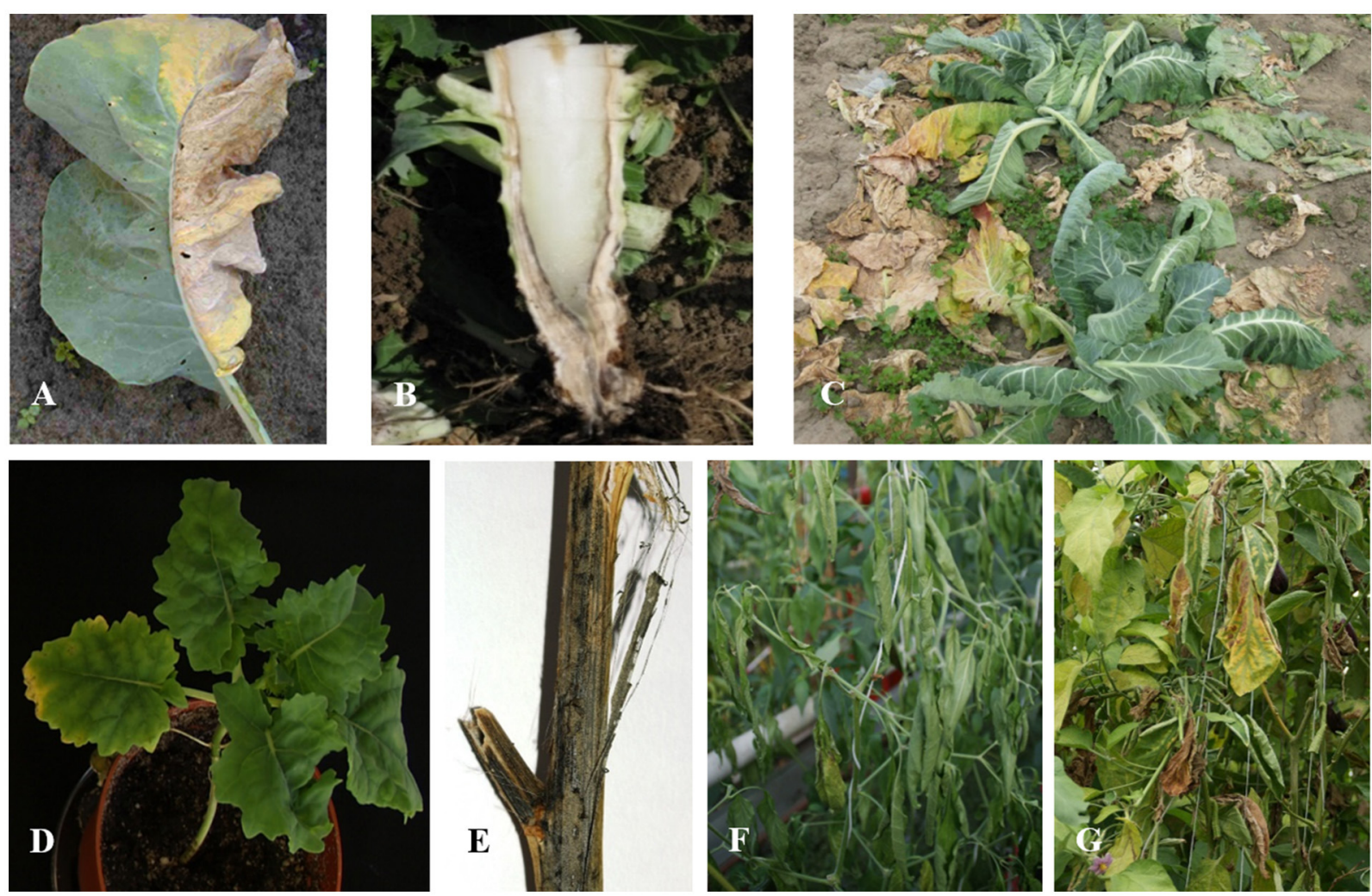

FIGURE 1 | Symptoms caused by Verticillium spp. Verticillium wilt of cauliflower (A-C): Asymmetric chlorosis of the leaves (A); Vascular discoloration of the stem (B); Wilting of cauliflower plants in the field (C). Verticillium symptoms on oilseed rape (D,E): Stunted growth and vein clearing in oilseed rape caused by artificial infection of $V$. longisporum (D); Verticillium stem striping in oilseed rape caused by $V$. longisporwn, formation of microsclerotia in the stem cortex beneath the epidermis (E). Pepper plants infected by $V$. dahliae showing wilted leaves (F). Eggplant infected by $V$. dahliae showing chlorosis and necrosis of leaves (G).

are available as biopesticide against Verticillium in Europe (http://ec.europa.eu/food/plant/pesticides/). To increase the use of BCAs in agriculture, some issues for successful practical implementation should be considered in the selection process of potential BCAs and good protocols of use are needed for farmers. In this review, we summarized the research about biocontrol against Verticillium wilt in various crops. The idea was to understand what makes a good BCA against Verticillium and how the development of these organisms into an effective biopesticide can be improved.

\section{BIOLOGICAL CONTROL OF VERTICILLIUM WILT}

We consulted the Web of Science database until February 28, 2017 using keywords such as "Verticillium," "Verticillium wilt," in combination with "biological control," "biocontrol," "crossprotection," and "endophytes" to search for relevant publications. Only studies in which the BCAs or their exudates were tested on plants were considered. Tables 2, 3 give an overview of respectively the bacterial and fungal/oomycete isolates tested against Verticillium wilt. In the table of the fungal and oomycete BCAs all isolates tested against Verticillium were included regardless of their effect and their control efficacy is indicated. The taxonomy of the species belonging to the Glomeromycota was adjusted according to the classification proposed by Schüßler and Walker (2010). A different approach was used for bacterial BCAs. Only isolates that could control Verticillium wilt and were identified at least to the genus level were included in the table. For each antagonist, the studied host plant, the effect on growth with and without Verticillium and the (possible) mode of action are shown.

\section{Studied Host Plants}

Pathogenic Verticillium species affect a wide variety of plants and in particular $V$. dahliae has a broad host range, including important agricultural crops, woody species, and ornamentals (Pegg and Brady, 2002; Inderbitzin and Subbarao, 2014). Biological control of Verticillium wilt, however, has only been investigated for a few host plants. Studies with bacterial isolates were performed on nine different host plants belonging to six plant families, while studies with fungal and oomycete isolates were performed on 17 different host plants of 11 plant families (Table 2, 3). Most biocontrol studies were focused on plants of the Solanaceae, Malvaceae, and Brassicaceae. In these families eggplant, cotton and oilseed rape were the most studied crops. Studies on economically important woody 
TABLE 2 | Bacterial isolates with biocontrol activity against Verticillium in different host plants.

\begin{tabular}{|c|c|c|c|c|c|}
\hline \multirow[t]{2}{*}{ Antagonist } & \multirow[t]{2}{*}{ Host } & \multicolumn{2}{|c|}{ Effect on growth(*) } & \multirow[t]{2}{*}{ Mode of action } & \multirow[t]{2}{*}{ References } \\
\hline & & $-\mathrm{Ve}$ & $+\mathrm{Ve}$ & & \\
\hline \multicolumn{6}{|l|}{ GRAM-POSITVE } \\
\hline \multicolumn{6}{|l|}{ Arthrobacter } \\
\hline Arthrobacter sp. FP15 & Eggplant & & & Reduced MS germination, antibiosis (iv), IR & Papasotiriou et al., 2013 \\
\hline \multicolumn{6}{|l|}{ Bacillus } \\
\hline B. amyloliquefaciens 41B-1 & Cotton & & & Reduced MS germination, antibiosis (iv), IR & Han et al., 2015 \\
\hline \multirow[t]{2}{*}{ B. amyloliquefaciens 5-127 } & Eggplant & & + & Antibiosis (iv), mycoparasitism (iv) & Tjamos et al., 2004 \\
\hline & Potato & & & Antibiosis (iv), mycoparasitism (iv) & Tjamos et al., 2004 \\
\hline $\begin{array}{l}\text { B. amyloliquefaciens UCMB-5033, } \\
\text { UCMB-5036, UCMB-5113 }\end{array}$ & Oilseed rape & + & & Antibiosis (iv) & Danielsson et al., 2007 \\
\hline B. cereus $\mathrm{CH} 2$ & Eggplant & & + & $\begin{array}{l}\text { Reduced spore germination (iv), antibiosis (iv), } \\
\text { mycoparasitism (iv) }\end{array}$ & Li et al., 2008 \\
\hline B. cereus AR156 & Cotton & + & + & Reduced spore germination (iv) & Yang et al., 2014 \\
\hline B. pumilus M1 & Potato & & & Antibiosis (iv) & Uppal et al., 2007, 2008 \\
\hline $\begin{array}{l}\text { B. subtilis B-26, B-121, B-135, } \\
\text { B-136, B-150, B-181 }\end{array}$ & Maple & & & Antibiosis (iv) & Hall et al., 1986 \\
\hline B. subtilis SM21 & Cotton & + & + & Reduced spore germination (iv) & Yang et al., 2014 \\
\hline B. subtilis YUPP-2 & Cotton & & & Antibiosis (iv) & Yang et al., 2013 \\
\hline B. subtilis Jaas ed 1 & Eggplant & & & Antibiosis (iv) & Lin et al., 2009 \\
\hline B. subtilis DF14 & Cotton & & & & Luo et al., 2010 \\
\hline B. subtilis TSO6 & Strawberry & + & & Reduced spore germination, antibiosis (iv) & Zhang Y. et al., 2012 \\
\hline B. subtilis HJ5 & Cotton & & & Antibiosis (iv), competition & Li et al., 2013 \\
\hline B. vallismortis $\mathrm{HJ}-5$ & Cotton & & + & & Zhang G. et al., 2012 \\
\hline Bacillus sp. K-160 & Eggplant & & + & Antibiosis (iv), mycoparasitism (iv) & Tjamos et al., 2004 \\
\hline \multicolumn{6}{|l|}{ Paenibacillus } \\
\hline \multirow[t]{4}{*}{ P. alvei K-165 } & Eggplant & & + & $\begin{array}{l}\text { Reduced MS germination, antibiosis (iv), } \\
\text { mycoparasitism (iv), IR }\end{array}$ & $\begin{array}{l}\text { Tjamos et al., 2004; } \\
\text { Antonopoulos et al., 2008; } \\
\text { Markakis et al., 2008; } \\
\text { Angelopoulou et al., } 2014\end{array}$ \\
\hline & Potato & & & Antibiosis (iv), mycoparasitism (iv) & Tjamos et al., 2004 \\
\hline & Arabidopsis & & & IR & $\begin{array}{l}\text { Tjamos et al., 2005; Gkizi } \\
\text { et al., } 2016\end{array}$ \\
\hline & Olive & & & & Markakis et al., 2016 \\
\hline P. polymyxa YUPP-8 & Cotton & & & Antibiosis (iv) & Yang et al., 2013 \\
\hline P. xylanilyticus YUPP-1 & Cotton & & & Antibiosis (iv) & Yang et al., 2013 \\
\hline \multicolumn{6}{|l|}{ Streptomyces } \\
\hline S. albidoflavus S1 & Strawberry & & & Antibiosis (iv), mycoparasitism (iv) & Berg et al., 2000 \\
\hline S. albidoflavus 1W1 & Strawberry & & + & & Berg et al., 2001 \\
\hline S. cyaneofuscatus ZY-153 & Cotton & + & 0 & Antibiosis (iv), mycoparasitism (iv), IR & Xue et al., 2013, 2016 \\
\hline S. diastatochromogenes S9 & Strawberry & & & Antibiosis (iv), mycoparasitism (iv) & Berg et al., 2000 \\
\hline S. flavotricini Z-13 & Cotton & + & 0 & Antibiosis (iv), mycoparasitism (iv), IR & Xue et al., 2013, 2016 \\
\hline S. kanamyceticu B-49 & Cotton & + & 0 & Antibiosis (iv), mycoparasitism (iv), IR & Xue et al., 2013, 2016 \\
\hline S. lividans 66 & Arabidopsis & + & + & $\begin{array}{l}\text { Reduced spore germination, reduced MS } \\
\text { formation, antibiosis (iv) }\end{array}$ & $\begin{array}{l}\text { Meschke and Schrempf, } \\
2010 \text {; Meschke et al., } \\
2012\end{array}$ \\
\hline $\begin{array}{l}\text { S. Iydicus WYEC108 (wood } \\
\text { chip-PAM cores) }\end{array}$ & Potato & & + & Competition & Entry et al., 2000 \\
\hline S. rimosus 7W1 & Strawberry & & 0 & & Berg et al., 2001 \\
\hline S. rochei X-4 & Cotton & + & + & Antibiosis (iv), mycoparasitism (iv), IR & Xue et al., 2013, 2016 \\
\hline Streptomyces sp. DHV3-2 & Tomato & + & + & Antibiosis (iv) & Cao et al., 2016 \\
\hline
\end{tabular}


TABLE 2 | Continued

\begin{tabular}{|c|c|c|c|c|c|}
\hline \multirow[t]{2}{*}{ Antagonist } & \multirow[t]{2}{*}{ Host } & \multicolumn{2}{|c|}{ Effect on growth( $\left.{ }^{*}\right)$} & \multirow[t]{2}{*}{ Mode of action } & \multirow[t]{2}{*}{ References } \\
\hline & & $-\mathrm{Ve}$ & $+V e$ & & \\
\hline \multicolumn{6}{|l|}{ GRAM-NEGATIVE } \\
\hline \multicolumn{6}{|l|}{ Acetobacter } \\
\hline A. aceti VINO2 & Olive & & & $\begin{array}{l}\text { Reduced MS germination, mycoparasitism } \\
\text { (iv) }\end{array}$ & Varo et al., 2016b \\
\hline \multicolumn{6}{|l|}{ Enterobacter } \\
\hline Enterobacter sp. AS09 & Oilseed rape & & + & Antibiosis (iv), mycoparasitism (iv) & Alström, 2001 \\
\hline Enterobacter sp. HA02 & Cotton & + & + & Mycoparasitism (iv) & Li et al., 2010, 2012 \\
\hline \multicolumn{6}{|l|}{ Pseudomonas } \\
\hline P. chlororaphis K15 & Strawberny & + & + & Antibiosis (iv), mycoparasitism (iv) & Berg et al., 2001 \\
\hline P. chlororaphis MA342 & Oilseed rape & + & + & & Abuamsha et al., 2011 \\
\hline P. fluorescens M-4 & Potato & 0 & + & Competition & Leben et al., 1987 \\
\hline P. fluorescens P6, P10 & Strawberry & & & Antibiosis (iv), mycoparasitism (iv) & Berg et al., 2000 \\
\hline P. fluorescens B6, B41 & Eggplant & & & Antibiosis (iv) & Malandraki et al., 2008 \\
\hline P. fluorescens DF37 & Potato & & & Antibiosis (iv) & Uppal et al., 2007, 2008 \\
\hline P. fluorescens PICF4, PICF6, PICF8 & Olive & 0 & + & Antibiosis (iv) & $\begin{array}{l}\text { Mercado-Blanco et al., } \\
\text { 2004; Varo et al., 2016b }\end{array}$ \\
\hline \multirow[t]{2}{*}{ P. fluorescens PICF7 } & Olive & 0 & + & Competition, IR & $\begin{array}{l}\text { Mercado-Blanco et al., } \\
\text { 2004; Prieto et al., 2009; } \\
\text { Schilirò et al., 2012; } \\
\text { Gómez-Lama Cabanás } \\
\text { et al., 2014; } \\
\text { Maldonado-González } \\
\text { et al., 2015b }\end{array}$ \\
\hline & Arabidopsis & & & & $\begin{array}{l}\text { Maldonado-González } \\
\text { et al., 2015a }\end{array}$ \\
\hline P. putida B E2 & Strawberny & + & + & Antibiosis (iv), mycoparasitism (iv) & Berg et al., 2001 \\
\hline P. putida PICP2 & Olive & 0 & 0 & Antibiosis (iv) & $\begin{array}{l}\text { Mercado-Blanco et al., } \\
2004\end{array}$ \\
\hline P. putida PICP5 & Olive & 0 & + & Antibiosis (iv) & $\begin{array}{l}\text { Mercado-Blanco et al., } \\
2004\end{array}$ \\
\hline $\begin{array}{l}\text { Pseudomonas sp. FP22, FP23, } \\
\text { FP30, FP35 }\end{array}$ & Cotton & + & + & Antibiosis (iv) & $\begin{array}{l}\text { Erdogan and Benlioglu, } \\
2010\end{array}$ \\
\hline \multicolumn{6}{|l|}{ Serratia } \\
\hline \multirow[t]{3}{*}{ S. plymuthica HRO-C48 } & Strawberry & + & + & Mycoparasitism (iv) & $\begin{array}{l}\text { Kalbe et al., 1996; Kurze } \\
\text { et al., } 2001\end{array}$ \\
\hline & Cotton & & + & Mycoparasitism (iv) & $\begin{array}{l}\text { Kalbe et al., 1996; } \\
\text { Erdogan and Benlioglu, } \\
2010\end{array}$ \\
\hline & Oilseed rape & + & + & Mycoparasitism (iv) & $\begin{array}{l}\text { Kalbe et al., 1996; Müller } \\
\text { and Berg, 2008; } \\
\text { Abuamsha et al., } 2011\end{array}$ \\
\hline Serratia sp. XY21 & Cotton & + & + & Reduced spore germination (iv) & Yang et al., 2014 \\
\hline \multicolumn{6}{|l|}{ Stenotrophomonas } \\
\hline S. maltophilia (isolate 1) & Oilseed rape & & & Antibiosis (iv), mycoparasitism (iv) & Berg et al., 1996 \\
\hline Stenotrophomonas AS10 & Oilseed rape & & + & Antibiosis (iv), mycoparasitism (iv) & Alström, 2001 \\
\hline
\end{tabular}

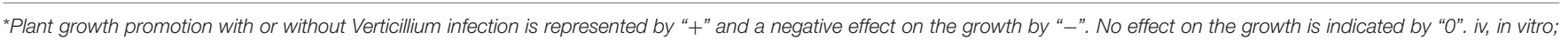
IR, Induced Resistance; PAM: polyacrylamide.

species and ornamentals are limited to olive and Acer species. This may indicate that isolates controlling Verticillium wilt of woody plants are hard to find. A more likely explanation is that investigating biocontrol in these plants is timeconsuming and labor-intensive. Moreover, except for maple and olive, Verticillium isolates of woody plants have not been studied extensively and information about their pathogenicity and genetic diversity is limited (Pegg and Brady, 2002; Chandelier et al., 2003; López-Escudero and Mercado-Blanco, 2011). 
TABLE 3 | Fungal and oomycete isolates with potential biocontrol activity against Verticillium in different host plants.

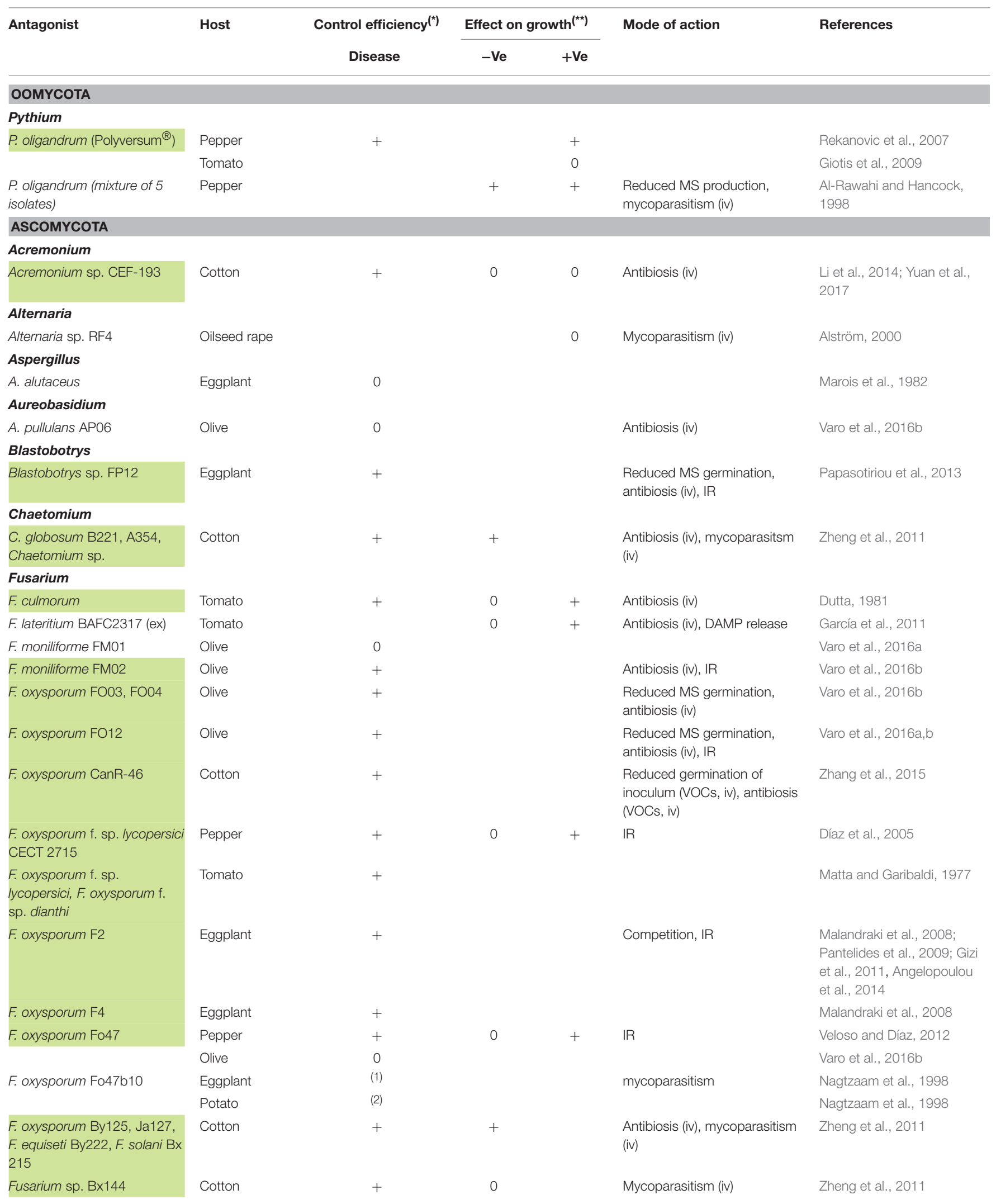


TABLE 3 | Continued

\begin{tabular}{|c|c|c|c|c|c|c|}
\hline Antagonist & Host & $\begin{array}{l}\text { Control efficiency }{ }^{(*)} \\
\text { Disease }\end{array}$ & \multicolumn{2}{|c|}{ Effect on growth $\left.{ }^{(\star *}\right)$} & Mode of action & References \\
\hline $\begin{array}{l}\text { Fusarium sp. MTB1, MNS1, } \\
\text { MNB3 }\end{array}$ & Eggplant & + & & & & Narisawa et al., 2002 \\
\hline Fusarium sp. RF6 & Oilseed rape & & & 0 & Parasitism (iv) & Alström, 2000 \\
\hline \multicolumn{7}{|l|}{ Gibellulopsis } \\
\hline $\begin{array}{l}\text { G. nigrescens (formerly } \\
\text { V. nigrescens) }\end{array}$ & Cotton & + & 0 & + & & $\begin{array}{l}\text { Vagelas and Leontopoulos, } \\
2015\end{array}$ \\
\hline \multicolumn{7}{|l|}{ Gliocladium } \\
\hline G. roseum GR01 & Olive & 0 & & & & Varo et al., 2016a \\
\hline Gliocladium sp. RF15 & Oilseed rape & & & 0 & Mycoparasitism (iv) & Alström, 2000 \\
\hline Gliocladium sp. & Tomato & + & + & + & $\begin{array}{l}\text { Antibiosis (iv), mycoparasitism } \\
\text { (iv) }\end{array}$ & Dutta, 1981 \\
\hline \multicolumn{7}{|l|}{ Heteroconium } \\
\hline H. chaetospira H4007 & $\begin{array}{l}\text { Chinese } \\
\text { cabbage }\end{array}$ & + & & 0 & & Narisawa et al., 2000, 2004 \\
\hline H. chaetospira MNB4 & Eggplant & + & & & & Narisawa et al., 2002 \\
\hline \multicolumn{7}{|l|}{ Leptosphaeria } \\
\hline Leptosphaeria sp. CEF-714 & Cotton & + & 0 & 0 & Antibiosis (iv) & $\begin{array}{l}\text { Li et al., 2014; Yuan et al., } \\
2017\end{array}$ \\
\hline \multicolumn{7}{|l|}{ Microsphaeropsis } \\
\hline \multicolumn{7}{|l|}{ Myrothecium } \\
\hline M. roridum A243 & Cotton & + & + & & Mycoparasitism (iv) & Zheng et al., 2011 \\
\hline \multicolumn{7}{|l|}{ Nectria } \\
\hline N. haematococca B×247 & Cotton & + & + & & Mycoparasitism (iv) & Zheng et al., 2011 \\
\hline \multicolumn{7}{|c|}{ Non sporulating fungus with white mycelium } \\
\hline SWM MHB2 & Eggplant & + & & & & Narisawa et al., 2002 \\
\hline \multicolumn{7}{|l|}{ Paecilomyces } \\
\hline P. lilacinus & Eggplant & + & & & & Marois et al., 1982 \\
\hline \multicolumn{7}{|l|}{ Penicillium } \\
\hline P. chrysogenum (dm) & Cotton & + & & & $\mathbb{I R}$ & Dong et al., 2003, 2006 \\
\hline P. chrysogenum & Cotton & + & & & & Zhang et al., 2011 \\
\hline P. chrysogenum EEZ10 (ex) & Tomato & & 0 & + & Antibiosis (iv), DAMP release & García et al., 2011 \\
\hline $\begin{array}{l}\text { P. chrysogenum, } P \text {. } \\
\text { vermiculatum, Penicillium sp. }\end{array}$ & Tomato & + & + & + & $\begin{array}{l}\text { Antibiosis (iv), mycoparasitism } \\
\text { (iv) }\end{array}$ & Dutta, 1981 \\
\hline P. oxalicum $\mathrm{PO} 212$ & Tomato & + & & & & $\begin{array}{l}\text { Larena et al., 2003; } \\
\text { Sabuquillo et al., 2005, } 2006\end{array}$ \\
\hline P. simplicissimum CEF-818 & Cotton & + & 0 & + & Antibiosis (iv), IR & $\begin{array}{l}\text { Li et al., 2014; Yuan et al., } \\
2017\end{array}$ \\
\hline Penicillium sp. MNT8 & Eggplant & + & & & & Narisawa et al., 2002 \\
\hline
\end{tabular}


TABLE 3 | Continued

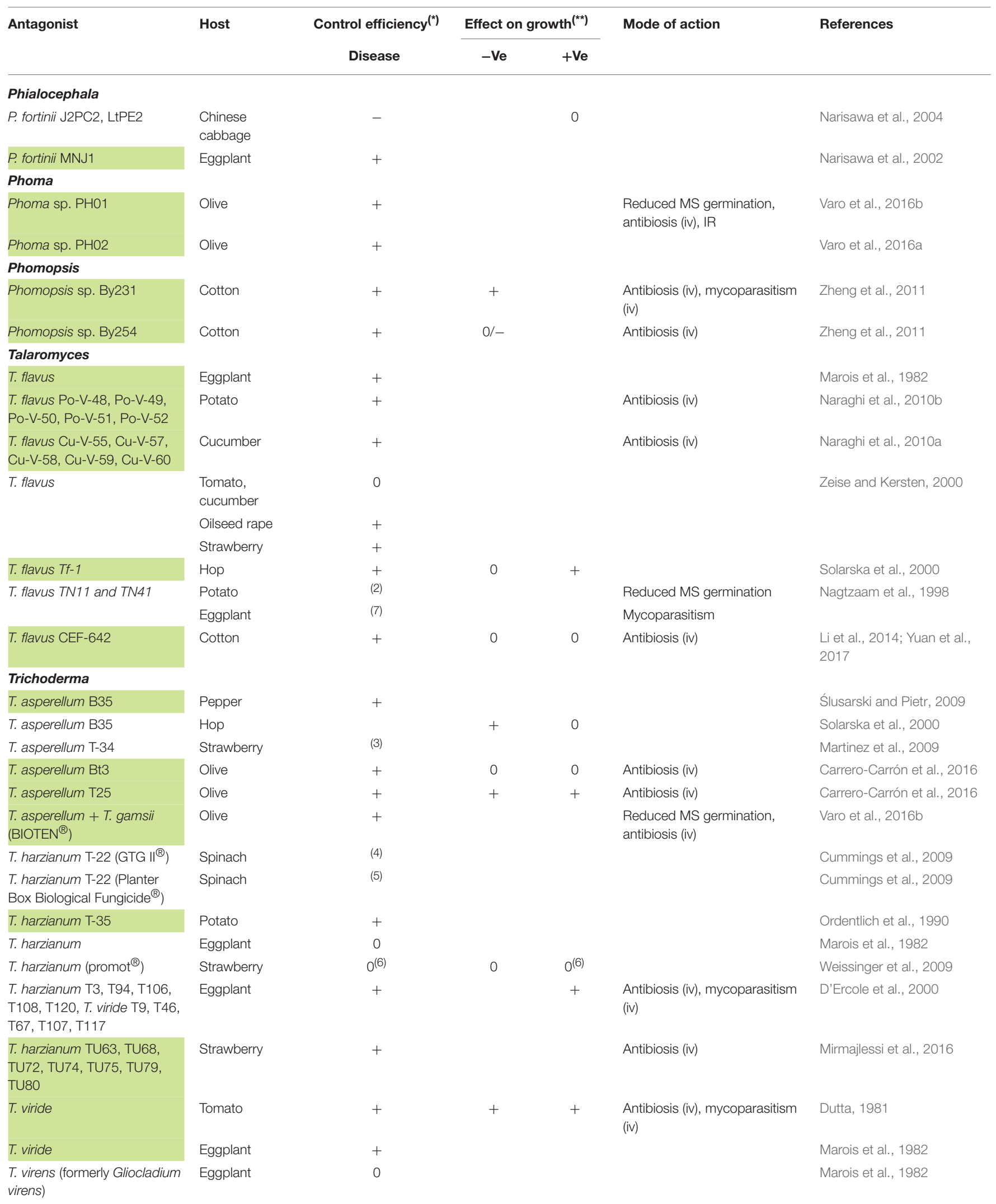


TABLE 3 | Continued

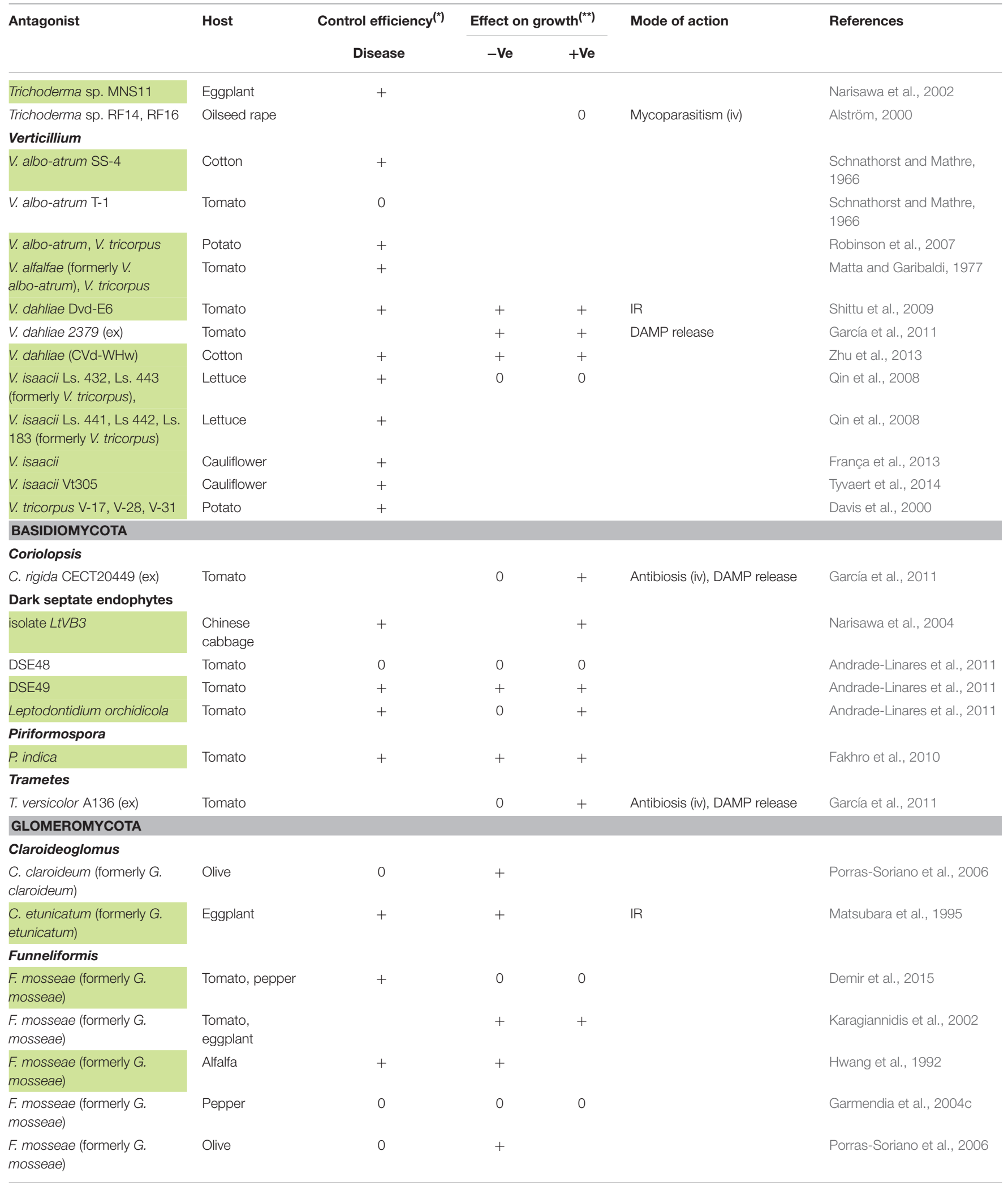


TABLE 3 | Continued

\begin{tabular}{|c|c|c|c|c|c|c|}
\hline Antagonist & Host & $\begin{array}{c}\text { Control efficiency }{ }^{(*)} \\
\text { Disease }\end{array}$ & \multicolumn{2}{|c|}{ Effect on growth $\left.{ }^{(\star *}\right)$} & Mode of action & References \\
\hline $\begin{array}{l}\text { F. mosseae (formerly G. } \\
\text { mosseae) + F. caledonium (G. } \\
\text { caledonium) }\end{array}$ & Tomato & 0 & 0 & 0 & & Baath and Hayman, 1983 \\
\hline G. margarita & Eggplant & + & + & & $\mathbb{R}$ & Matsubara et al., 1995 \\
\hline \multicolumn{7}{|l|}{ Glomus } \\
\hline G. deserticola & Pepper & + & 0 & 0 & $\mathbb{R}$ & $\begin{array}{l}\text { Garmendia et al., 2004a,b,c; } \\
\text { Garmendia et al., } 2006\end{array}$ \\
\hline G. hoi & Cotton & + & 0 & 0 & & Liu, 1995 \\
\hline $\begin{array}{l}\text { R. fasciculatus (formerly G. } \\
\text { fasciculatus) }\end{array}$ & Alfalfa & + & + & & & Hwang et al., 1992 \\
\hline $\begin{array}{l}\text { R. fasciculatus (formerly G. } \\
\text { fasciculatus) }\end{array}$ & Cotton & 0 & + & 0 & & Davis et al., 1979 \\
\hline $\begin{array}{l}\text { R. intraradices (formerly G. } \\
\text { intraradices) }\end{array}$ & Eggplant & + & 0 & 0 & & Demir et al., 2015 \\
\hline $\begin{array}{l}\text { R. intraradices (formerly } G \text {. } \\
\text { intraradices) }\end{array}$ & Pepper & 0 & 0 & 0 & & Garmendia et al., 2004c \\
\hline $\begin{array}{l}\text { R. intraradices (formerly G. } \\
\text { intraradices) }\end{array}$ & Olive & 0 & + & & & Porras-Soriano et al., 2006 \\
\hline $\begin{array}{l}\text { R. intraradices (formerly G. } \\
\text { intraradices) }\end{array}$ & Olive & 0 & + & & & Kapulnik et al., 2010 \\
\hline
\end{tabular}

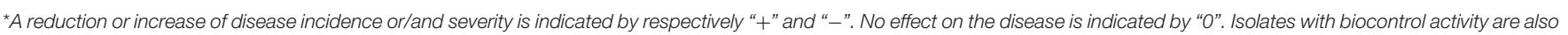

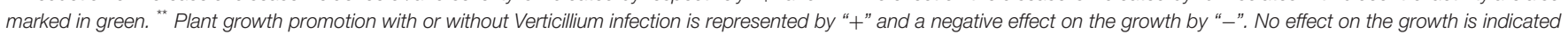

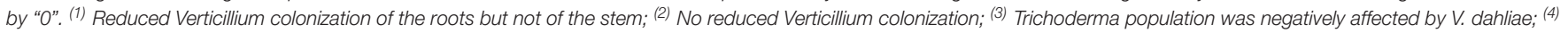

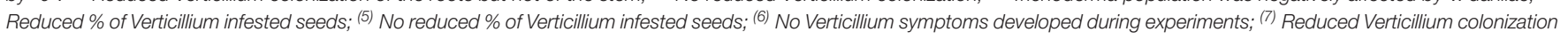
of the roots and stem. ex, exudates of the isolate were used to apply to the plants; $d m$, dry mycelium of the isolate was applied to the plants; iv, in vitro; IR, Induced Resistance.

It should be noted that many of the potential BCAs were tested only once. The reasons can be that those isolates (1) were studied for scientific purposes only, (2) were not considered for further research or (3) insufficient control was established.

\section{Bacterial Biocontrol Agents}

The potential of bacterial endophytes as biocontrol agents of vascular wilts has recently been reviewed by Eljounaidi et al. (2016). In our study, we specifically focused on Verticillium wilt and included also non-endophytic bacterial BCAs. We divided bacterial biocontrol agents in Grampositive and Gram-negative bacteria and further arranged them according to their genus (Table 2). Within the Gram-positive bacteria, strains belonging to the genera Arthrobacter, Bacillus, Paenibacillus, and Streptomyces have been studied. Bacillus species comprise the largest group within the Gram-positive bacteria, followed by Streptomyces and Paenibacillus species. The Gram-negative strains belong to the genera Acetobacter, Enterobacter, Pseudomonas, Serratia, and Stenotrophomonas, with Pseudomonas as the largest pool of potential BCAs of Verticillium.

The genus Bacillus is well-explored in the search of BCAs to control Verticillium wilt. Over two third of the Bacillus strains tested belong to the species Bacillus amyloliquefaciens and Bacillus subtilis. Remarkably, only the Bacillus strain B. amyloliquefaciens 5-127, isolated from tomato roots, was tested on different host plants. B. amyloliquefaciens 5-127 reduced the percentage of diseased leaves by $40-70 \%$ in eggplants challenged with $V$. dahliae in the greenhouse and could reduce disease incidence with more than $50 \%$ in a field experiment with potato (Tjamos et al., 2004). In one of the few studies regarding biological control of Verticillium wilt in trees, several B. subtilis 
isolates were tested in the greenhouse against $V$. dahliae in maple tree. These isolates were obtained from healthy maple stem tissue and decreased disease incidence of $V$. dahliae in maple trees by 34-51\% (Hall et al., 1986). Bacillus strains were also reported to protect cotton, strawberry and oilseed rape against Verticillium wilt (Table 2).

Paenibacillus isolates have recently gained interest as promising BCAs of plant diseases (Lal and Tabacchioni, 2009; Rybakova et al., 2016). Paenibacillus alvei K-165 was isolated from tomato root tips grown in solarized soil (Tjamos et al., 2004) and its biocontrol activity against $V$. dahliae in eggplant has repeatedly been shown in greenhouse experiments (Tjamos et al., 2004; Antonopoulos et al., 2008; Markakis et al., 2008; Angelopoulou et al., 2014). This strain also reduced the disease incidence in potato under field conditions and suppressed Verticillium wilt of olive tree under both greenhouse and field conditions (Tjamos et al., 2004; Markakis et al., 2016). In cotton, application of the Paenibacillus isolates P. xylanilyticus YUPP-1 and Paenibacillus polymyxa YUPP-8 resulted in a lower disease incidence and decreased severity of Verticillium (Yang et al., 2013).

Various species of Streptomyces have been studied in relation to their biological control effect against Verticillium. Xue et al. (2013) selected four Streptomyces strains isolated from the rhizosphere of different crops and evaluated their antagonistic potential against $V$. dahliae in cotton. Under greenhouse conditions the biocontrol efficacy ranged between 19 and 66\%, while in field conditions the biocontrol efficacies of the four Streptomyces isolates were slightly lower and ranged between 14 and $51 \%$ depending on the application method. Co-inoculation of Arabidopsis thaliana seeds with $V$. dahliae and Streptomyces lividans 66 led to a strong suppression of the fungus within soil, which resulted in a strong reduction of Verticillium-induced disease symptoms (Meschke and Schrempf, 2010). In potato, tomato and strawberry, Streptomyces species reduced the disease incidence and/or severity in greenhouse experiments (Berg et al., 2000, 2001; Entry et al., 2000; Cao et al., 2016). However, the biofungicide Mycostop ${ }^{\circledR}$ based on S. griseovirides K61 did not offer significant protection against $V$. dahliae in tomato (Minuto et al., 2006).

Pseudomonas spp. have been extensively studied as BCA of different pathogens including Verticillium. Most of the tested potential biocontrol strains belong to the fluorescent Pseudomonas group. Root treatment of olive plants with root-associated fluorescent pseudomonads during nursery propagation could suppress Verticillium wilt in olive caused by defoliating $V$. dahliae (Mercado-Blanco et al., 2004; Prieto et al., 2009). Other isolates of the fluorescent Pseudomonas group can be protective against $V$. dahliae in crops such as potato, strawberry, and eggplant (Leben et al., 1987; Berg et al., 2000, 2001; Malandraki et al., 2008; Uppal et al., 2008). Seed treatment with $P$. chlororaphis strain MA 342, the active organism in the biopesticides Cedomon ${ }^{\circledR}$ and Cerall ${ }^{\circledR}$ (BioAgri AB, Uppsala, Sweden), resulted in a lower infection of oilseed rape with $V$. longisporum (Abuamsha et al., 2011). The study of Erdogan and Benlioglu (2010) indicated that the Pseudomonas strains FP22, FP23, FP30 and FP35 are good biocontrol candidates against Verticillium wilt of cotton and moreover can improve the growth parameters in cotton fields.

Isolates of the Gram-negative genus Serratia have frequently been found associated with plant roots and possess antifungal properties (Grimont and Grimont, 1992; Kalbe et al., 1996). The biocontrol strain Serratia plymuthica HRO-C48 successfully controlled Verticillium wilt in strawberry fields (Kurze et al., 2001). Furthermore, treating the seeds of oilseed rape with S. plymuthica $\mathrm{HRO}-\mathrm{C} 48$ via bio-priming, pelleting or seed coating suppressed Verticillium wilt in oilseed rape plants (Müller and Berg, 2008). Seed treatment with S. plymuthica HRO-C48 could also protect cotton plants against Verticillium wilt (Erdogan and Benlioglu, 2010).

The application of specific isolates belonging to the genera Arthrobacter, Acetobacter, Enterobacter, and Stenotrophomonas resulted in protection of eggplant, olive, cotton and oilseed rape against Verticillium wilt (Berg et al., 1996; Alström, 2001; Li et al., 2012; Papasotiriou et al., 2013; Varo et al., 2016b).

\section{Fungal and Oomycete Biocontrol Agents}

Fungal and oomycete isolates tested as BCA against Verticillium are listed in Table 3. The majority of isolates belong to the Ascomycota and a minor fraction of the isolates belong to the Basidiomycota and Glomeromycota. Only one Oomycete, Pythium oligandrum, has been investigated. Studies with Trichoderma, Fusarium, and Verticillium isolates as potential biocontrol agent were the most prevalent. Isolates of Talaromyces, Funneliformis, Rhizophagus, Glomus, and Penicillium have been studied more than three times. Isolates of other species were less frequently considered as BCA.

Talaromyces flavus reduced Verticillium disease of eggplant and potato with more than $75 \%$ in naturally infested soils (Marois et al., 1982; Naraghi et al., 2010b). Different formulations of $T$. flavus were tested (Nagtzaam et al., 1998; Zeise and Kersten, 2000), but up to date none of them have been registered in the European Union (http://ec.europa.eu/food/plant/pesticides).

Control of Verticillium by arbuscular mycorrhizal fungi (AMF) of the Glomeromycota is variable. Twelve of the tested strains could effectively protect plants against the disease with a maximum reduction of the disease incidence with $65 \%$, while some of the AMF even worsened the disease (Davis et al., 1979; Porras-Soriano et al., 2006). Interestingly, Glomus deserticola influenced the plant phenology of pepper plants which contributed to more resistant or tolerant plants to pathogen attack (Garmendia et al., 2004c).

Some Penicillium isolates or their exudates or dry mycelium were tested for potential biocontrol. In cotton, the application of dry mycelium resulted in a control efficacy of $27-50 \%$ depending on the applied dose (Dong et al., 2006). Exudates of Penicillium chrysogenum EEZ10 decreased the negative effect of Verticillium on the plant growth of tomato (García et al., 2011). The formulation of Penicillium oxalicum PO-212 spores influenced the efficacy: mixing the conidia with the substrate gave better control compared to applying the conidial suspension immediately to the seedbed (Larena et al., 2003). 
A lot of isolates belonging to Trichoderma have been evaluated for their capacity to control Verticillium wilt with variable successes. Ten Trichoderma isolates were tested by D'Ercole et al. (2000) and Trichoderma viride T46 and T117 resulted in the best protection with a reduction of the disease incidence of $30 \%$ in eggplant. Three strains reduced the disease with more than $80 \%$ in tomato, eggplant and pepper (Dutta, 1981; Narisawa et al., 2002; Ślusarski and Pietr, 2009). In the case of respectively Trichoderma asperellum B35 and Trichoderma harzianum T-35, the efficacy of control depended on several factors such as the field location of the experiments and the type of formulation (Ordentlich et al., 1990; Ślusarski and Pietr, 2009). In olive, T. asperellum isolates T25 and Bt3 and application of BIOTEN ${ }^{\circledR}$ (T. asperellum + T. gamsii) reduced the disease severity of Verticillium wilt but not the incidence (Carrero-Carrón et al., 2016; Varo et al., 2016b).

Recently, Fusarium oxysporum isolates have gained interest as BCA against Verticillium wilt. F. oxysporum is also a soilborne fungi and able to colonize and penetrate the roots of host plants. F. oxysporum F2 has been extensively studied for its biocontrol capacity on eggplant and reduced disease severity and colonization by $V$. dahliae (Malandraki et al., 2008; Pantelides et al., 2009; Gizi et al., 2011; Angelopoulou et al., 2014). The strain was applied by seed treatment or amendment to the transplant soil plug. This last strategy gave the best results with a dose dependent response. Pepper and olive plants treated with $F$. oxysporum isolate Fo47 exhibited reduced symptoms (Veloso and Díaz, 2012; Varo et al., 2016b). In the case of olive, the F. oxysporum isolates FO04 and FO12 showed stronger biocontrol activity against Verticillium wilt than isolate Fo47 (Varo et al., 2016a,b). In cotton, F. oxysporum By125 and F. oxysporum CanR-46 reduced disease severity with respectively 69 and $92 \%$ (Zheng et al., 2011; Zhang et al., 2015). Applying exudates of Fusarium lateritium to tomato roots decreased the negative effect of $V$. dahliae on the growth of the plants (García et al., 2011).

Different isolates belonging to $V$. dahliae, Verticillium albo-atrum, Verticillium isaacii, Verticillium tricorpus, and Gibellulopsis nigrescens (formerly Verticillium nigrescens) protected plants against a virulent relative of Verticillium spp. The isolate $V$. dahliae Dvd-E6 was non-pathogenic on tomato and conferred protection to tomato plants challenged with the pathogen $V$. dahliae. The order of inoculation of both isolates influenced the level of protection (Shittu et al., 2009). Applying exudates of $V$. dahliae 2379 to tomato roots decreased plant growth reduction by a pathogenic $V$. dahliae isolate (García et al., 2011). In cotton, Verticillium wilt was reduced by V. albo-atrum SS-4 and G. nigrescens (Schnathorst and Mathre, 1966; Zhu et al., 2013; Vagelas and Leontopoulos, 2015). In all those studies, preinoculation of the protective isolate appeared to be more robust at reducing Verticillium symptoms relative to co-inoculation. The amount of inoculum applied also played a role for the level of protection by $V$. albo-atrum SS-4 (Schnathorst and Mathre, 1966). Two isolates, $V$. dahliae Dvd-E6 and $V$. albo-atrum SS-4, were able to reduce symptom development in respectively tomato and cotton, but were pathogenic on other host plants (Schnathorst and Mathre, 1966; Dobinson et al., 1998).
$V$. tricorpus and $V$. isaacii (formerly $V$. tricorpus) were both associated with soil suppressiveness of Verticillium wilt in respectively potato and cauliflower fields (Davis et al., 2000; França et al., 2013). V. isaacii Vt305, an isolate obtained from the suppressive cauliflower field, has shown to be able to reduce symptom development and colonization by $V$. longisporum of cauliflower (Tyvaert et al., 2014). The control was dependent on the applied dose of both the pathogen and the BCA. Robinson et al. (2007) found that $V$. tricorpus reduced Verticillium disease of potato with $74 \%$ in a field experiment and pre-inoculation resulted in the best protection. In the same study, protection by a $V$. albo-atrum isolate was comparable. Also the colonization of the different potato tissues by the pathogenic $V$. albo-atrum isolate was remarkably reduced by pre-inoculation with $V$. tricorpus or $V$. albo-atrum. Several $V$. isaacii isolates reduced Verticillium wilt of lettuce and pretreatment appeared to provide better protection than co-inoculation (Qin et al., 2008).

\section{Modes of Action of the Studied BCAs}

Several modes of action are known to be involved in biological disease control, but the underlying mechanisms of specific interactions with pathogenic Verticillium isolates are often unknown. The modes of action reported for the different genera of antagonists against Verticillium wilt are shown in Table 4. Figure 2 shows how BCAs can interfere with different steps in the infection cycle of Verticillium. Direct microbial antagonism involves parasitism of the fungus and its surviving structures, competition for nutrients and infection sites or antibiosis. This leads to less inoculum present in the rhizosphere or a lower infection potential of the pathogen. Indirect mechanisms include plant growth promotion and induced resistance. Several bacterial and fungal BCAs promote plant growth and in this way the deleterious effects of Verticillium wilt are reduced. Induced resistance can also contribute to the protection against Verticillium wilt, particularly if this process is initiated in the root tissue which is primarily colonized by the pathogen. Often, several mechanisms are expressed by a single biocontrol agent and one mode of action does not necessarily excludes another.

\section{Reducing Germination of Inoculum}

Especially in the case of a monocyclic disease such as Verticillium wilt, reducing the germination of primary inoculum is an interesting mode of action of potential BCAs. Root application of the BCAs P. alvei K-165, Arthrobacter sp. FP15 and Blastobotrys sp. FP12 resulted in the reduction of microsclerotia germination of $V$. dahliae in the rhizosphere of eggplants (Antonopoulos et al., 2008; Papasotiriou et al., 2013). Al-Rawahi and Hancock (1998) furthermore demonstrated that P. oligandrum was able to parasitize $V$. dahliae and to impede its microsclerotia formation. Interestingly, the BCA $T$. flavus decreased the viability of $V$. dahliae microsclerotia on senescent potato stems, which eventually could limit the release of these surviving structures to the soil (Nagtzaam et al., 1998). Mycofumigation with the volatile organic compounds of Muscodor albus, Muscodor roseus, and F. oxysporum CanR-46 also effectively reduced inoculum density of $V$. dahliae in the soil, thereby suppressing Verticillium wilt in respectively eggplant and cotton (Stinson 
TABLE 4 | Mode of action of selected biocontrol agents against Verticillium wilt.

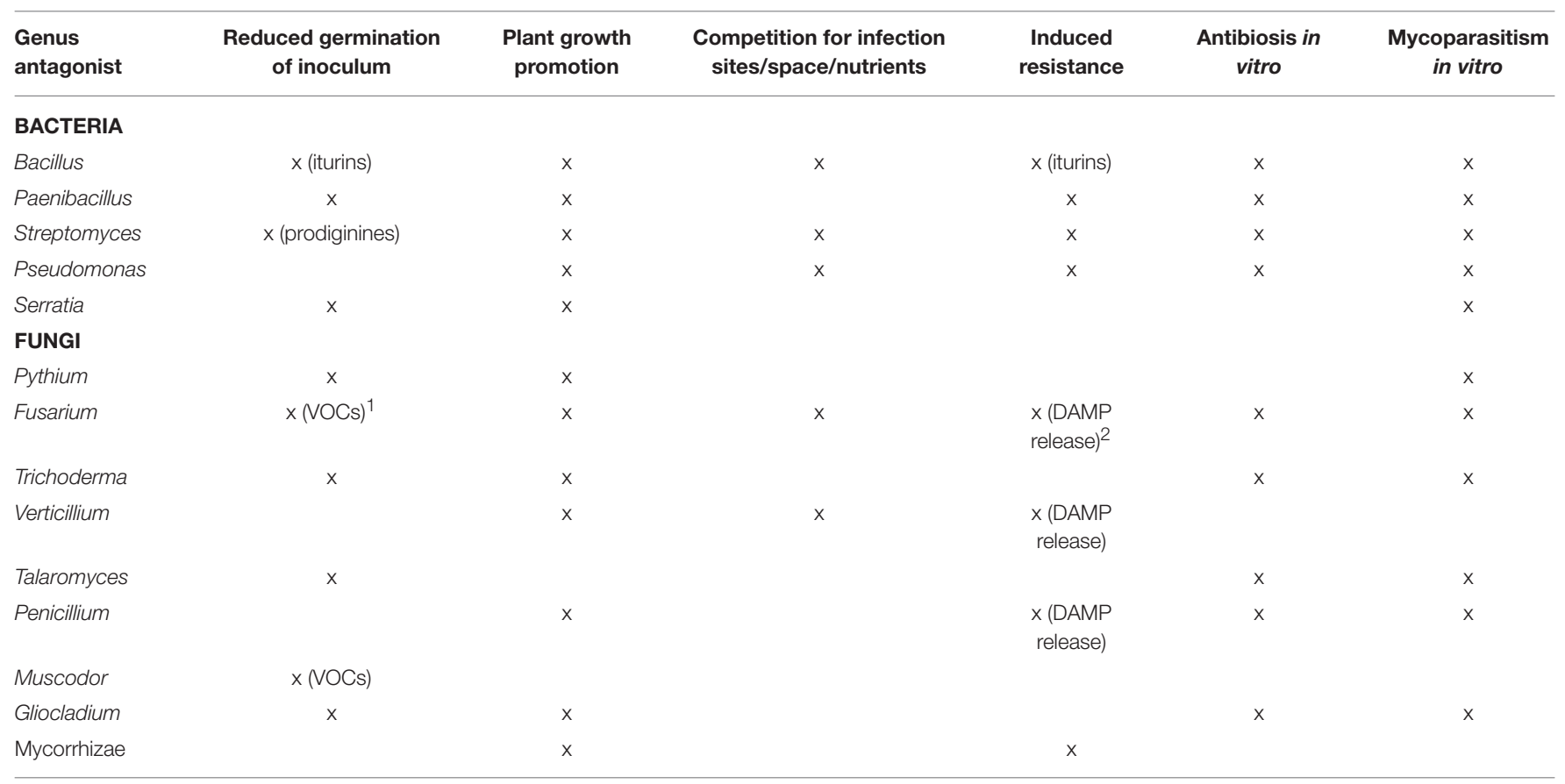

${ }^{1}$ VOCs: volatile compounds.

${ }^{2}$ DAMP: damage associated molecular pattern.

et al., 2003; Zhang et al., 2015). In addition, the iturins of the culture filtrate of $B$. amyloliquefaciens 41B-1 suppressed $V$. dahliae microsclerotial germination, while the prodiginines produced by $S$. lividans reduced the formation of $V$. dahliae microsclerotia (Meschke et al., 2012; Han et al., 2015). The importance of biosurfactant production in the suppression of Verticillium microsclerotia viability by Pseudomonas spp. has only been shown in vitro (Debode et al., 2007). The germination of $V$. dahliae microsclerotia was also reduced by several Gliocladium roseum strains (Keinath et al., 1991; Varo et al., 2016b). Remarkably, effects of BCAs on surviving mycelium and chlamydospores were not reported. A possible explanation is that almost all BCAs have been tested against $V$. dahliae and $V$. longisporum, which only form microsclerotia to survive in soil (Table 1).

\section{Growth Promotion}

BCAs of Verticillium often promote root and/or shoot growth and this has been reported for isolates of the bacterial genera Bacillus, Paenibacillus, Streptomyces, Enterobacter, Pseudomonas, and Serratia, and the fungal(-like) genera Pythium, Fusarium, Nectria, Trichoderma, Verticillium, Penicillium, Phomopsis, and AMF. The plant growth promoting effect of BCAs can counteract the adverse effect of pathogenic Verticillium species on the yield of crops as exemplified by the interaction of S. plymuthica R12 and $V$. dahliae in strawberry. Although treatment of strawberry with this Serratia strain resulted in a higher disease incidence of Verticillium wilt, a five-fold enhancement of the number of stolons and a yield enhancement of more than $70 \%$ was found (Berg et al., 2001). Production of plant growth hormones may be involved in improving plant growth mediated by the BCAs. Auxin production was demonstrated in vitro for some bacterial BCAs such as B. amyloliquefaciens 5-127, P. alvei K165, and S. plymuthica HRO-C48 (Kalbe et al., 1996; Tjamos et al., 2004). Besides mechanisms involving phytohormones, enhanced growth may also be exerted by improved nutrient acquisition (Berg, 2009). Soil inoculation with a consortium of three plantgrowth promoting rhizobacteria, active against Verticillium in cotton, improved soil properties in field experiments, including an increase in organic matter and the availability of nitrogen, phosphorus and potassium (Yang et al., 2014). AMF are known to promote plant growth and several of them reduce Verticillium wilt in solanaceous plants and alfalfa (Hwang et al., 1992; Liu, 1995; Matsubara et al., 1995; Karagiannidis et al., 2002; Garmendia et al., 2004a,b,c, 2006; Demir et al., 2015). Treatment with Funneliformes mosseae resulted in a higher phosphorus and nitrogen uptake in tomato and eggplant (Karagiannidis et al., 2002). Also pepper plants associated with G. deserticola had a higher phosphorus uptake (Garmendia et al., 2004b). This increased capacity for nutrient uptake could contribute to diminish the deleterious effect of the pathogen (Karagiannidis et al., 2002; Garmendia et al., 2004b).

\section{Competition}

Competition for space, infection sites and nutrients is wellestablished as working mechanism of BCAs and was suggested to be involved in the interaction between Verticillium and several biocontrol isolates of Bacillus, Streptomyces, Pseudomonas, Verticillium, and Fusarium. For Verticillium, particularly competition for nutrients and/or infection sites in the soil and 

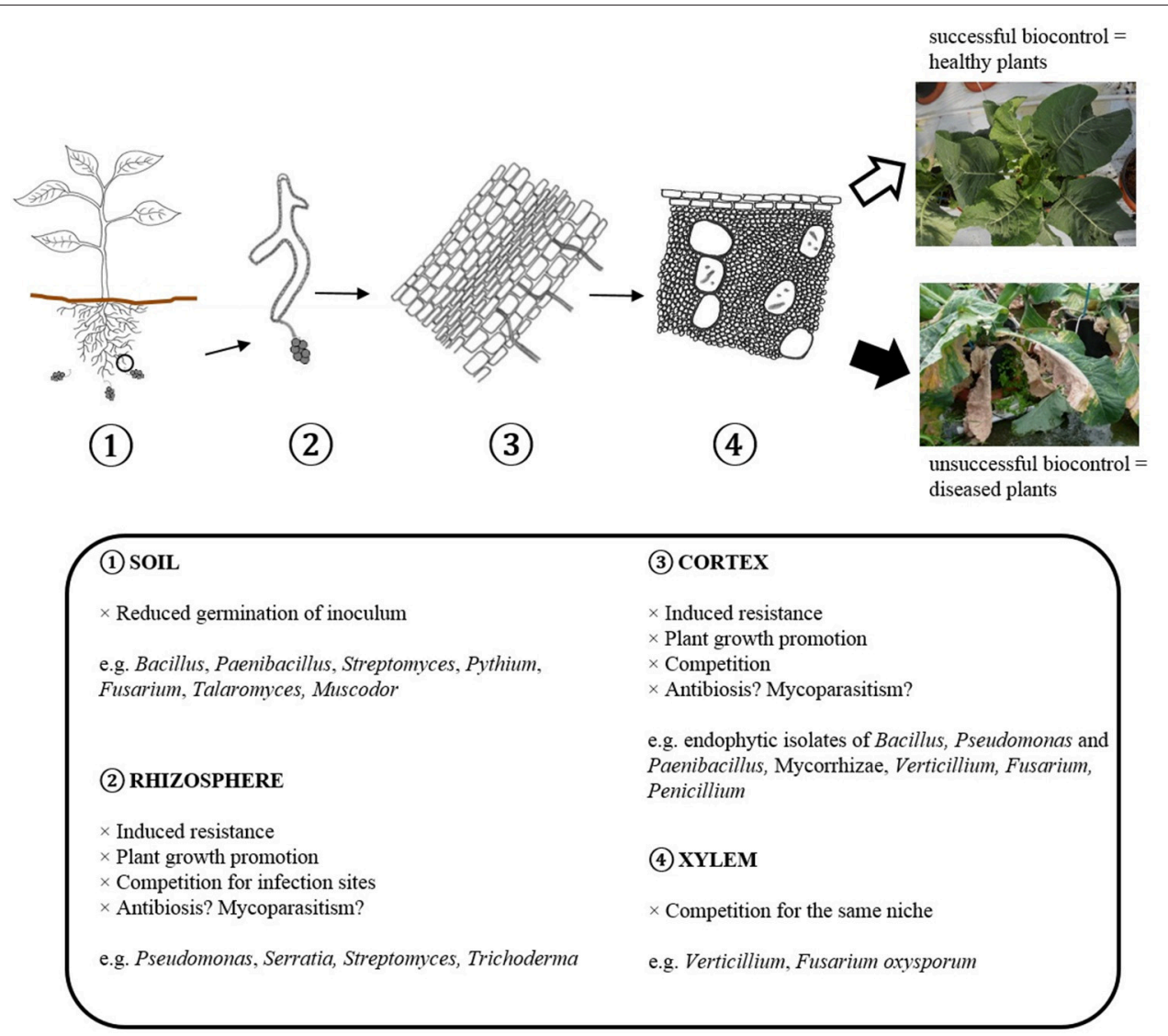

FIGURE 2 | Scheme showing how BCAs can interfere with different steps in the infection cycle of Verticillium.

in/on the roots may be an efficient mode of action in controlling the disease. It is expected that bacterial BCAs compete for nutrients and infection sites in the rhizosphere and cortex, while BCAs such as Verticillium and Fusarium can also colonize the xylem and occupy the same niche as Verticillium. A commonly cited example of competition is that for iron. Under iron-limiting conditions, bacteria produce siderophores with high affinity for ferric iron. By binding available iron these bacteria prevent the pathogens' access to the limited pool of soluble iron in the rhizosphere and in that way the growth of the pathogen is hindered (Loper and Buyer, 1991; Loper and Henkels, 1999). The in vitro production of siderophores was shown for a number of BCAs with antagonistic effect on Verticillium (Berg et al., 1996, 2000; Mercado-Blanco et al., 2004; Li et al., 2010; Xue et al., 2013). However, Maldonado-González et al. (2015a,b) showed that siderophore production is not required for biological control of Verticillium wilt by Pseudomonas fluorescens PICF7.

\section{Induced Resistance}

Induced resistance has frequently been proposed to be part of the working mechanism of the BCAs. Evidence of triggering plant defense responses was provided for antagonistic isolates of the bacterial genera Arthrobacter, Bacillus, Paenibacillus, Streptomyces, and Pseudomonas, and of the fungal genera Fusarium, Verticillium, Penicillium, Blastobotrys, Coriolopsis, and
Trametes. Also AMF of the genera Glomus, Gigaspora and Claroideoglomus were able to induce resistance. P. alvei K-165 and F. oxysporum F2 induced the expression of defense-related genes $P R 1$ and $P R 4$ in eggplant. Moreover, the expression of these genes was positively correlated with the rhizosphere population of both BCAs (Angelopoulou et al., 2014). In Arabidopsis, it has been shown that the resistance induced by $P$. alvei $\mathrm{K}$ 165 against $V$. dahliae is dependent on both salicylate and jasmonate-dependent defense pathways (Tjamos et al., 2005; Gkizi et al., 2016). Results of a split-root experiment indicated the involvement of induced resistance in the protection of eggplant against $V$. dahliae by Arthrobacter sp. FP15 and Blastobotrys sp. FP12 (Papasotiriou et al., 2013). The endophytic BCA P. fluorescens PICF7 has been shown to activate an array of defense pathways in the roots and aerial tissues of olive upon colonization of the roots (Schilirò et al., 2012; GómezLama Cabanás et al., 2014). Recently, Gómez-Lama Cabanás et al. (2017) demonstrated that the expression of defense-related genes differed depending on whether or not $V$. dahliae and $P$. fluorescens PICF7 colonized the same sectors of the roots of olive plants. Interestingly, no biocontrol was observed when $V$. dahliae and P. fluorescens PICF7 were spatially separated. In the case of B. amyloliquefaciens 41B-1, iturins could induce plant defense responses and mediate pathogen-associated molecular pattern (PAMP)-triggered immunity against $V$. dahliae in cotton 
(Han et al., 2015). Applying exudates of several saprobe fungi (Coriolopsis rigida, Trametes versicolor, F. lateritium, $P$. chrysogenum, and the non-pathogenic $V$. dahliae-2379) could control $V$. dahliae disease of tomato probably through hydrolyzing root cell wall components. This generates damage associated patterns (DAMPs) which could act as elicitors of plant defense (García et al., 2011). PAMPs and DAMPs can be recognized by specific membrane-bound receptors in the plant, leading to PAMP-triggered immunity (PTI; Boller and Felix, 2009; Zipfel, 2014). Induced resistance by AMF resulted in a more balanced antioxidant metabolism (Garmendia et al., 2004a), the induction of defense-related enzymes (Garmendia et al., 2006) and accumulation of lignin in the roots (Matsubara et al., 1995).

\section{What about Cross-Protection?}

The protection of plants against virulent Verticillium spp. by closely related isolates that are non-pathogenic on that specific host has often been described as cross-protection. Only in a few studies the underlying mechanisms of this phenomenon were elucidated (Shittu et al., 2009; García et al., 2011). Mechanisms involved include induced resistance, competition for space (including infection sites) and nutrients, and plant growth promotion. In vitro, it was often shown that neither isolate is inhibitory to the other. The best protection is accomplished if the protective isolates are applied to the plants before challenge treatment with the pathogen. Also the concentrations of inoculum of both the pathogen and the beneficial organism are of importance for the level of control (Shittu et al., 2009; Tyvaert et al., 2014). Verticillium species have proven to expand their host range and the stability of the interaction between non-pathogenic and pathogenic isolates remains an open question (Shittu et al., 2009).

\section{What about Antibiosis and Mycoparasitism of Verticillium Mycelium?}

The majority of BCAs included in this study showed in vitro antagonism against Verticillium mycelium (Tables 2, 3, 4) but a possible role of antibiosis in biocontrol in planta has not been demonstrated. Only when production at the site of biocontrol is demonstrated or when activity is proved by the use of non-producing or over-producing mutants, or reporter strains, the role of metabolites in disease biocontrol can be confirmed (Whipps and McQuilken, 2009). To our knowledge, these types of studies have not been reported for Verticillium biocontrol. Another type of direct antagonism is mycoparasitism and the associated production of extracellular lytic enzymes. Chitinases, proteases, and glucanases are produced in vitro by many of the studied BCAs of Verticillium, but clear evidence that these enzymes play a role in the direct interaction with the pathogen in the presence of plants is lacking. Regarding the life cycle of Verticillium, germination of survival structures such as microsclerotia is stimulated by the direct vicinity of germinating seeds or plant roots. Root penetration and subsequent colonization of the xylem vessels can be achieved within only 2-4 days (Heinz et al., 1998; Chen et al., 2004; Fradin and Thomma, 2006). Possibilities for reducing mycelial growth in the rhizosphere by direct antagonism may therefore be limited. Direct antagonism in planta is only possible for those BCAs that are able to colonize the cortex or xylem. The production of antibiotics and inhibitory metabolites is influenced by plant type and age, nutrient availability, environmental conditions, microorganisms present and the pathogen itself (Molina et al., 2003; Duffy et al., 2004; Maurhofer et al., 2004; Morello et al., 2004; Compant et al., 2005). It is not clear if conditions inside the plant are conducive for the production of antimicrobial compounds. In planta studies on the behavior of BCAs are limited but for $T$. harzianum, the interaction with $V$. dahliae in olive was investigated. Mycoparasitism of $V$. dahliae by $T$. harzianum occurred in vitro, although there was no evidence that this also happens in planta (Ruano-Rosa et al., 2016). In this context, it is interesting to notice that control of Verticillium by Trichoderma, for which the main modes of action include antibiosis and mycoparasitism, is limited. Trichoderma is one of the most studied and successful BCAs, with many commercial products that are used in practice to control a variety of soil-borne pathogens such as Rhizoctonia, Fusarium, Sclerotinia, Botrytis, and Pythium. Possibly, Trichoderma strains were originally selected for control of other soil-borne pathogens and were later on tested against Verticillium. Therefore, not the best strains for biocontrol of Verticillium might have been selected. Interestingly, it was shown by Carrero-Carrón et al. (2016) that T. asperellum T25 that was effective in controlling Verticillium disease in olive had the highest ability to grow endophytically in the roots. But in comparison with other isolates, it had the lowest inhibitory effect on the in vitro growth of $V$. dahliae. The capacity of a biocontrol strain to compete for the same ecological niche of Verticillium could be crucial, indicating that selection criteria should not focus on in vitro antagonism.

\section{WHAT ARE THE KEY FACTORS IN THE PROCESS FROM SELECTION OF THE BCA TO SUCCESSFUL IMPLEMENTATION?}

From our survey of biocontrol studies we can conclude that common BCAs such as Trichoderma, Pythium, Gliocladium, and $\mathrm{AMF}$ are not the best candidates for augmentative biological control of Verticillium wilt. Few studies reported the biocontrol effect of Gliocladium on Verticillium wilt. Some Gliocladium strains could reduce microsclerotia viability in soil conditions, but the number of reports about successful biocontrol in planta is limited (Keinath et al., 1991; Varo et al., 2016b). The biopesticide Polyversum ${ }^{\circledR}$, containing P. oligandrum, showed no control of Verticillium in one study and in another study, it resulted in variable control (Al-Rawahi and Hancock, 1998; Rekanovic et al., 2007). Some of the Trichoderma strains (T. asperellum T34, T. harzianum T-22) were shown to be able to reduce Fusarium wilt (Cotxarrera et al., 2002; Gilardi et al., 2007; Sant et al., 2010) and are approved by the EU as biopesticide against Fusarium but not against Verticillium. It would be expected that F. oxysporum and Verticillium can be controlled by the same BCAs because they have apparently similar characteristics. 
Both pathogens share the same ecological niche: they are soilborne pathogens able to colonize the vascular system with the production of similar symptoms. A closer look to the infection and colonization process gives evidence for some important differences. Verticillium inhabits the lower parts of the plant for a longer time than F. oxysporum (Klimes et al., 2015). F. oxysporum has a higher degree of host specialization and produces symptoms faster (Klosterman et al., 2011). The $V$. dahliae enzyme VdThi4, required for biosynthesis of a thiamine (vitamin B1), has been shown to play a role in the colonization process. VdThi4 deletion mutants are unable to colonize the upper portion of the plant. In F. oxysporum, however, the VdThi4 homolog stri35 was not required for virulence (Hoppenau et al., 2014). Tomato plant cells respond differently to infection by both pathogens (Ferraris et al., 1974; Cooper and Wood, 1980; Bishop and Cooper, 1983a,b). Recently, genomic insights into both pathogens revealed some differences in the secretome. More specifically, a protein family involved in attachment to plant cell walls and increase of enzyme efficiency was expanded in Verticillium (Klosterman et al., 2011). These differences may explain why some BCAs are effective against Fusarium but not against Verticillium.

\section{Where to Look for Potential BCAs?}

Disease suppressive soils are an interesting source of BCAs with potential against soil-borne diseases (Cook, 1985). Fusarium suppressive soils have extensively been studied while soil suppressiveness for Verticillium is rarely reported. A strain of F. oxysporum (Fo47) originated from suppressive soils for Fusarium wilt of tomato and had also biocontrol activity against Verticillium wilt on pepper (Veloso and Díaz, 2012). Keinath and Fravel (1992) demonstrated that by successive croppings, some soils exhibit induced suppressiveness to Verticillium wilt of potato. Only a few studies were carried out with isolates from suppressive soils for Verticillium wilt of potato and cauliflower. From these soils non-pathogenic Verticillium isolates, belonging to $V$. tricorpus and $V$. isaacii, were obtained that could control Verticillium wilt in potato and cauliflower (Davis et al., 2000; França et al., 2013; Tyvaert et al., 2014).

Organic amendments have proven to be disease suppressive and are therefore interesting reservoirs of potential BCAs. Several isolates controlling Verticillium wilt were obtained from suppressive composts: two F. oxysporum and two P. fluorescens isolates originated from the rhizosphere of eggplants grown in soil amended with disease suppressive compost (Malandraki et al., 2008), while the isolates belonging to Arthrobacter and Blastobotrys were obtained from disease suppressive olive mill compost (Papasotiriou et al., 2013). Another strategy to look for successful BCAs is to identify healthy plants in infested fields. In this way a Nectria isolate and two B. subtilis isolates with biocontrol activity against Verticillium were recovered from healthy cotton roots in infested soil (Luo et al., 2010; Zheng et al., 2011; Li et al., 2013). Most of the other bacterial BCAs described in Table 2 were obtained from the rhizosphere or roots of host plants. The origin of the fungal BCAs described in Table 3 is not always indicated. Clearly, not a lot of the studied isolates were obtained from sources giving already some evidence for biological control. It does not necessarily mean that those isolates perform better but at least they are expected to establish better in field conditions, as they are able to colonize the soil or host plants.

\section{Desirable Characteristics}

The ability to affect surviving structures of Verticillium by antibiosis or mycoparasitism is a desirable trait of BCAs resulting in a reduction of the primary inoculum. Selection of BCAs sharing the same ecological niche as Verticillium is promising, since these organisms can compete with Verticillium for infection sites, space and nutrients. For instance in the tripartite interaction $V$. dahliae-olive- $P$. fluorescens PICF7, niche overlap between the BCA and the pathogen in planta was necessary for effective biocontrol (Gómez-Lama Cabanás et al., 2017). Efficient root colonizers can compete with Verticillium for infection sites. In addition, they may protect the plant by triggering induced resistance by secreting PAMPs or releasing DAMPs from plant cells. BCAs with an endophytic lifestyle that colonize the cortex and/or the xylem are protected against adverse environmental conditions, and can exclude Verticillium from the same niche by competition for space and nutrients, as exemplified by a non-pathogenic F. oxysporum (Pantelides et al., 2009), or by inducing resistance responses in the plant as shown for Bacillus spp. (Han et al., 2015). Often, nonpathogenic fungi that are closely related to the pathogen can successfully control disease in naturally infested soils (Herr, 1995; Gutteridge et al., 2007; Alabouvette et al., 2009). In the case of Verticillium wilt this has been demonstrated for non-pathogenic Verticillium isolates. However, it is important to confirm that these isolates are really non-pathogenic on a wide range of plants. Finally, the ability to promote plant growth can compensate for some of the deleterious effects caused by pathogenic Verticillium spp. In vitro screening for antimicrobial activity against Verticillium mycelium correlates poorly or not at all with biocontrol activity in planta and does not seem to be the best strategy to look for good Verticillium BCAs.

The ability to control Verticillium in several host plants or to control other soil-borne and/or vascular pathogens, is interesting to increase the market potential of the BCA. Several BCAs able to reduce Verticillium disease were also effective in controlling other diseases and examples are summarized hereafter. Nonpathogenic F. oxysporum isolates also controlled Fusarium wilt and Phytophthora root rot and blight of pepper plants (Díaz et al., 2005; Veloso and Díaz, 2012). Cotton plants treated with dry mycelium of $P$. chrysogenum exhibited reduced symptoms of Verticillium and Fusarium wilt (Dong et al., 2006; Zhang et al., 2011). Mycofumigation with Muscodor spp. could control seedling diseases of sugar beet next to Verticillium wilt of eggplant (Stinson et al., 2003). Besides its biocontrol effect on $V$. dahliae in eggplant and potato, the bacterial BCA P. alvei K-165 reduced root discoloration and hypocotyl lesions caused by the black root rot fungus Thielaviopsis basicola on cotton seedlings (Tjamos et al., 2004; Schoina et al., 2011). Pseudomonas chlororaphis MA 342, which suppressed V. longisporum in oilseed rape, furthermore controls a wide range of cereal seed-borne 
diseases and is the active organism in the registered products Cedomon ${ }^{\circledR}$ and Cerall ${ }^{\circledR}$ (Johnsson et al., 1998; Abuamsha et al., 2011).

Omics technologies are an interesting tool for the selection of promising BCAs, as these technologies allow in-depth characterization of the strain. The modes of action of a BCA can be identified by characterization of genes, mRNAs, and proteins. Also the properties of strains with different control efficacy can be compared. This may lead to the selection of BCAs with the best control potential in terms of efficacy and consistency (Massart et al., 2015).

\section{Evaluation of Biocontrol Activity}

Experiments with BCAs are often carried out in sterile soils using plants that have been artificially inoculated with Verticillium via root dipping in a conidial suspension or via soil drench with a conidial suspension. These experimental conditions are quite different from natural infested field conditions. First of all, in sterile soils, the BCA can easily establish, while BCAs often fail to work in the field due to more complex conditions. Secondly, disease development in sterile soils is fast and often leads to severe symptoms. This can be a disadvantage for the BCA and possibly some effective BCAs are not selected because they seem of minor importance during the selection procedure in sterile conditions. Preferentially, experiments should be carried out with naturally infested soil, in field and greenhouse conditions, or by using microsclerotia as primary inoculum. In addition, the plants should be observed until the onset of flowering as the spread of Verticillium in the host tissue has been suggested to be induced by the initiation of flowering (Veronese et al., 2003; Zhou et al., 2006). Also screening for BCAs that target the primary inoculum should be done in conditions that mimic the natural situation. For instance, Microsphaeropsis ochracea reduced the microsclerotia viability in sterile soils but not in unsterile soils and failed to control Verticillium wilt of oilseed rape in the field (Stadler and von Tiedemann, 2014). It is therefore interesting to start screening for biocontrol strains from the field, to perform subsequently experiments in controlled conditions and to go back to the field finally.

\section{Formulation and Application}

In order to develop a promising BCA into a commercial product, large scale production, formulation, preservation conditions, shelf life, and application methods should be investigated. Nowadays, researchers interested in biocontrol are becoming more aware of the importance of these issues in product development.

Fungi and bacteria that produce surviving structures are interesting because these structures can be used as the active substance of the biocontrol product. Usually they are persistent to adverse environmental conditions and can be preserved and distributed without special requirements. Therefore, sporulating Gram-positive microorganisms, such as Bacillus and Streptomyces, are preferred rather than Gram-negative bacteria. Soil-borne fungi usually produce surviving structures such as chlamydospores in the case of F. oxysporum and microsclerotia in case of Verticillium species. A possible disadvantage of surviving structures is that the production process might be complex leading to a higher cost. Also the ability of those BCAs to become persistent in the new environment should be considered. The capacity of a strain to produce different structures is a desirable characteristic for application in different crop systems.

Application of the Verticillium BCAs close to the roots, where Verticillium initially infect the plants, could be the most effective strategy. The early introduction of the BCA by seed treatment and treatment of seedlings at the nursery stage could provide better relief from subsequent Verticillium infection than when the BCA is applied directly to the field. In the case of seed treatment, compatibility with standard seed treatments should be ensured. BCAs that can reduce germination of primary inoculum could be added to compost amendments or to the substrate.

Combining two or more BCAs is another interesting approach to improve the efficacy of biocontrol or to control different pathogens and even pests. Therefore, the application of the specific isolates should be compatible without reducing their single effect. Yang et al. (2013) showed that the combined application of three endophytic bacterial strains resulted in a better biocontrol efficacy of Verticillium wilt in cotton than their individual applications, which was probably linked to the fact that the different strains are predominant in different developmental stages of cotton. Also the application of a consortium of three rhizobacteria, Bacillus cereus AR156, B. subtilis SM21 and Serratia sp. XY21, resulted in higher biocontrol efficacy against Verticillium wilt in cotton compared to the individual strains (Yang et al., 2014). For other plant pathogens, it has been shown that mixtures of bacterial and fungal BCAs are more effective in controlling diseases such as Rhizoctonia and Pythium (Colla et al., 2012). The strength of a mixture is that BCAs can be combined that interact in a different way with the pathogen and/or the plant. Moreover, if conditions are not favorable for one of the BCAs, the other can take over. The drawback is that all isolates used in the mixture need to be registered.

The reliability of a product based on microbial BCAs is a crucial issue in ensuring long-term acceptance and sustained use by farmers. Standardized guidelines for quality control of the (potential) commercially available BCAs may help to avoid failures in their practical application and to prevent the application of organisms with detrimental effects. Parameters to be considered include content of fertilizers, presence of contaminants, traceability of the origin of the BCA, possible allelopathic effects of the BCA on the germination of some plant species and effectiveness under various conditions.

As Verticillium wilt is an emerging problem in different crops, some agricultural systems seem to promote Verticillium disease. Therefore, it could be difficult to reach satisfactory levels of control of Verticillium with a BCA in such a system. To implement biocontrol as a tool of IPM in agriculture, the current approach should be changed to a holistic management (van Lenteren et al., 2017). 


\section{CONCLUSION}

The application of BCAs is an interesting building block of sustainable and environmentally sound management strategies of Verticillium wilt. A holistic management should be considered to reach satisfactory levels of control by a BCA. Based on the number of currently known isolates with biocontrol activity against Verticillium species, the predominant genera are Pseudomonas, Bacillus, Fusarium, and Verticillium. Particularly soils or organic amendments suppressive for Verticillium disease and healthy plants in infested fields are attractive spots to find (new) BCAs of Verticillium. The ability to affect survival structures, sharing the same ecological niche as Verticillium, inducing resistance responses in the plant and promoting plant growth are desirable characteristics of a competent BCA against Verticillium wilt. Evaluating the biocontrol efficacy of BCAs in conditions that mimic the field situation is expected to significantly improve the chance of successful application in

\section{REFERENCES}

Abuamsha, R., Salman, M., and Ehlers, R. U. (2011). Differential resistance of oilseed rape cultivars (Brassica napus ssp. oleifera) to Verticillium longisporum infection is affected by rhizosphere colonisation with antagonistic bacteria, Serratia plymuthica and Pseudomonas chlororaphis. Biocontrol 56, 101-112. doi: 10.1007/s10526-010-9308-8

Alabouvette, C., Olivain, C., Migheli, Q., and Steinberg, C. (2009). Microbiological control of soil-borne phytopathogenic fungi with special emphasis on wilt-inducing Fusarium oxysporum. New Phytol. 184, 529-544. doi: 10.1111/j.1469-8137.2009.03014.x

Al-Rawahi, A. K., and Hancock, J. G. (1998). Parasitism and biological control of Verticillium dahliae by Pythium oligandrum. Plant Dis. 82, 1100-1106. doi: 10.1094/PDIS.1998.82.10.1100

Alström, S. (2000). Root-colonizing fungi from oilseed rape and their inhibition of Verticillium dahliae. J. Phytopathol. 148, 417-423. doi: 10.1046/j.1439-0434.2000.00511.x

Alström, S. (2001). Characteristics of bacteria from oilseed rape in relation to their biocontrol activity against Verticillium dahliae. J. Phytopathol. 149, 57-64. doi: 10.1046/j.1439-0434.2001.00585.x

Andrade-Linares, D. R., Grosch, R., Restrepo, S., Krumbein, A., and Franken, P. (2011). Effects of dark septate endophytes on tomato plant performance. Mycorrhiza 21, 413-422. doi: 10.1007/s00572-010-0351-1

Angelopoulou, D. J., Naska, E. J., Paplomatas, E. J., and Tjamos, S. E. (2014). Biological control agents (BCAs) of Verticillium wilt: influence of application rates and delivery method on plant protection, triggering of host defence mechanisms and rhizosphere populations of BCAs. Plant Pathol. 63, 1062-1069. doi: 10.1111/ppa.12198

Antonopoulos, D. F., Tjamos, S. E., Antoniou, P. P., Rafeletos, P., and Tjamos, E. C. (2008). Effect of Paenibacillus alvei, strain K165, on the germination of Verticillium dahliae microsclerotia in planta. Biol. Control 46, 166-170. doi: $10.1016 /$ j.biocontrol.2008.05.003

Baath, E., and Hayman, D. S. (1983). Plant growth responses to vesiculararbuscular mycorrhizae 14. Interactions with Verticillium wilt on tomato plants. New Phytol. 95, 419-426. doi: 10.1111/j.1469-8137.1983.tb03509.x

Berg, G. (2009). Plant-microbe interactions promoting plant growth and health: perspectives for controlled use of microorganisms in agriculture. Appl. Microbiol. Biotechnol. 84, 11-18. doi: 10.1007/s00253-009-2092-7

Berg, G., Fritze, A., Roskot, N., and Smalla, K. (2001). Evaluation of potential biocontrol rhizobacteria from different host plants of Verticillium dahliae Kleb. J. Appl. Microbiol. 91, 963-971. doi: 10.1046/j.1365-2672.2001.01462.x

Berg, G., Kurze, S., Buchner, A., Wellington, E. M., and Smalla, K. (2000). Successful strategy for the selection of new strawberry-associated rhizobacteria practice. In order to facilitate the further commercialization of a promising BCA of Verticillium, potential bottlenecks such as large-scale production, formulation, preservation conditions, shelf life, and application methods, should be tackled early in the selection process.

\section{AUTHOR CONTRIBUTIONS}

SD wrote the part about bacteria involved in biocontrol against Verticillium and made the figures. LT wrote the part about fungi involved in biocontrol against Verticillium and helped in making the figures. SD and LT contributed equally. SF and MH revised the manuscript and helped in structuring and editing the work.

\section{FUNDING}

Government agency for Innovation in Science and Technology (IWT-Vlaanderen). Grant number IWT 100886. antagonistic to Verticillium wilt. Can. J. Microbiol. 46, 1128-1137. doi: 10.1139/w00-101

Berg, G., Marten, P., and Ballin, G. (1996). Stenotrophomonas maltophilia in the rhizosphere of oilseed rape - occurrence, characterization and interaction with phytopathogenic fungi. Microbiol. Res. 151, 19-27. doi: 10.1016/S0944-5013(96)80051-6

Bishop, C. D., and Cooper, R. M. (1983a). An ultrastructural study of root invasion in three vascular wilt diseases. Physiol. Plant Pathol. 22, 15-27. doi: 10.1016/S0048-4059(83)81034-0

Bishop, C. D., and Cooper, R. M. (1983b). An ultrastructural study of vascular colonization in three vascular wilt diseases I. Colonization of susceptible cultivars. Physiol. Plant Pathol. 23, 323-343. doi: 10.1016/0048-4059(83)90018-8

Boller, T., and Felix, G. (2009). A renaissance of elicitors: perception of microbe-associated molecular patterns and danger signals by pattern-recognition receptors. Annu. Rev. Plant Biol. 60, 379-406. doi: 10.1146/annurev.arplant.57.032905.105346

Cao, P., Liu, C., Sun, P., Fu, X., Wang, S., Wu, F., et al. (2016). An endophytic Streptomyces sp. strain DHV3-2 from diseased root as a potential biocontrol agent against Verticillium dahliae and growth elicitor in tomato (Solanum lycopersicum). Antonie van Leeuwenhoek 109, 1573-1582. doi: 10.1007/s10482-016-0758-6

Carrero-Carrón, I., Trapero-Casas, J. L., Olivares-García, C., Monte, E., Hermosa, R., and Jiménez-Díaz, R. M. (2016). Trichoderma asperellum is effective for biocontrol of Verticillium wilt in olive caused by the defoliating pathotype of Verticillium dahliae. Crop Prot. 88, 45-52. doi: 10.1016/j.cropro.2016. 05.009

Chandelier, A., Laurent, F., Dantinne, D., Mariage, L., Etienne, M., and Cavelier, M. (2003). Genetic and molecular characterization of Verticillium dahliae isolates from woody ornamentals in Belgian nurseries. Eur. J. Plant Pathol. 109, 943-952. doi: 10.1023/B:EJPP.0000003682.18838.cf

Chen, P., Lee, B., and Robb, J. (2004). Tolerance to a non-host isolate of Verticillium dahliae in tomato. Physiol. Mol. Plant Pathol. 64, 283-291. doi: 10.1016/j.pmpp.2004.10.002

Colla, P., Gilardi, G., and Gullino, M. L. (2012). A review and critical analysis of the European situation of soilborne disease management in the vegetable sector. Phytoparasitica 40, 515-523. doi: 10.1007/s12600-012-0252-2

Compant, S., Duffy, B., Nowak, J., Clement, C., and Barka, E. A. (2005). Use of plant growth-promoting bacteria for biocontrol of plant diseases: principles, mechanisms of action, and future prospects. Appl. Environ. Microbiol. 71, 4951-4959. doi: 10.1128/AEM.71.9.4951-4959.2005

Cook, R. J. (1985). Biological control of plant pathogens: theory and application. Phytopathology 75, 25-29. doi: 10.1094/Phyto-75-25 
Cooper, R. M., and Wood, R. K. S. (1980). Cell wall degrading enzymes of vascular wilt fungi. III. Possible involvement of endo-pectin lyase in Verticillium wilt of tomato. Physiol. Plant Pathol. 16, 285-300. doi: 10.1016/0048-4059(80) 90043-0

Cotxarrera, L., Trillas-Gay, M. I., Steinberg, C., and Alabouvette, C. (2002). Use of sewage sludge compost and Trichoderma asperellum isolates to suppress Fusarium wilt of tomato. Soil Biol. Biochem. 34, 467-476. doi: 10.1016/S0038-0717(01)00205-X

Cummings, J. A., Miles, C. A., and du Toit, L. J. (2009). Greenhouse evaluation of seed and drench treatments for organic management of soilborne pathogens of spinach. Plant Dis. 93, 1281-1292. doi: 10.1094/PDIS-93-12-1281

Danielsson, J., Reva, O., and Meijer, J. (2007). Protection of Oilseed Rape (Brassica napus) Toward Fungal Pathogens by Strains of Plant-associated Bacillus amyloliquefaciens. Microb. Ecol. 54, 134-140. doi: 10.1007/s00248-0069181-2

Davis, J. R., Everson, D. O., Sorensen, L. H., and Schneider, A. T. (2000). "Associations of Verticillium tricorpus with soil suppressiveness of Verticillium wilt of potato," in Advances in Verticillium Research and Disease Management, eds E. C. Tjamos, R. C. Rowe, J. B. Heale, and D. R. Fravel (St. Paul, MN: APS Press), 347-351.

Davis, R. M., Menge, J. A., and Erwin, D. C. (1979). Influence of Glomus fasciculatus and phosphorus on Verticillium wilt of cotton. Phytopathology 69, 453-456. doi: 10.1094/Phyto-69-453

Debode, J., De Maeyer, K., Perneel, M., Pannecoucque, J., De Backer, G., and Höfte, M. (2007). Biosurfactants are involved in the biological control of Verticillium microsclerotia by Pseudomonas spp. J. Appl. Microbiol. 103, 1184-1196. doi: 10.1111/j.1365-2672.2007.03348.x

Demir, S., Șensoy, S., Ocak, E., Şefik, T., Demirer Durak, E., Erdinç, Ç., et al. (2015). Effects of arbuscular mycorrhizal fungus, humic acid, and whey on wilt disease caused by Verticillium dahliae Kleb. in three solanaceous crops. Turk. J. Agric. For. 39, 300-309. doi: 10.3906/tar-1403-39

Depotter, J. R. L., Deketelaere, S., Inderbitzin, P., von Tiedemann, A., Höfte, M., Subbarao, K. V., et al. (2016). Verticillium longisporum, the invisible threat to oilseed rape and other brassicaceous plant hosts. Mol. Plant Pathol. 17, 1004-1016. doi: 10.1111/mpp.12350

D’Ercole, N., Nipoti, P., Di Pillo, L., and Gavina, F. (2000). "In vitro and in vivo tests of Trichoderma spp. as a biocontrol agent of Verticillium dahliae Kleb. in eggplants," in Advances in Verticillium Research and Disease Management, eds E. C. Tjamos, R. C. Rowe, J. B. Heale, and D. R. Fravel (St. Paul, MN: APS Press), 260-263.

Díaz, J., Silvar, C., Varela, M. M., Bernal, A., and Merino, F. (2005). Fusarium confers protection against several mycelial pathogens of pepper plants. Plant Pathol. 54, 773-780. doi: 10.1111/j.1365-3059.2005.01285.x

Dobinson, K. F., Patterson, N. A., White, G. J., and Grant, S. (1998). DNA fingerprinting and vegetative compatibility analysis indicate multiple origins for Verticillium dahliae race 2 tomato isolates from Ontario, Canada. Mycol. Res. 102, 1089-1095. doi: 10.1017/S0953756297006035

Dobinson, K. F., Tenuta, G. K., and Lazarovits, G. (1996). Occurrence of race 2 of Verticillium dahliae in processing tomato fields in southwestern Ontario. Can. J. Plant Pathol 18, 55-58. doi: 10.1080/07060669609500655

Dong, H., Li, W., Zhang, D., and Tang, W. (2003). Differential expression of induced resistance by an aqueous extract of killed Penicillium chrysogenum against Verticillium wilt of cotton. Crop Prot. 22, 129-134. doi: 10.1016/S0261-2194(02)00122-9

Dong, H., Zhang, X., Choen, Y., Zhou, Y., Li, W., and Li, Z. (2006). Dry mycelium of Penicillium chrysogenum protects cotton plants against wilt diseases and increases yield under field conditions. Crop Prot. 25, 324-330. doi: 10.1016/j.cropro.2005.05.003

Duffy, B., Keel, C., and Defago, G. (2004). Potential role of pathogen signaling in multitrophic plant-microbe interactions involved in disease protection. Appl. Environ. Microbiol. 70, 1836-1842. doi: 10.1128/AEM.70.3.1836-1842.2004

Dutta, B. K. (1981). Studies on some fungi isolated from the rhizosphere of tomato plants and the consequent prospect for the control of Verticillium wilt. Plant Soil 63, 209-216. doi: 10.1007/BF02374599

Eljounaidi, K., Lee, S. K., and Bae, H. (2016). Bacterial endophytes as potential biocontrol agents of vascular wilt diseases - Review and future prospects. Biol. Control 103, 62-68. doi: 10.1016/j.biocontrol.2016.07.013
Entry, J. A., Strasbaugh, C. A., and Sojka, R. E. (2000). Wood chip-polyacrylamide medium for biocontrol bacteria decreases Verticillium dahliae infection on potato. Biocontrol Sci. Technol. 10, 677-686. doi: 10.1080/095831500750016479 Erdogan, O., and Benlioglu, K. (2010). Biological control of Verticillium wilt on cotton by the use of fluorescent Pseudomonas spp. under field conditions. Biol. Control 53, 39-45. doi: 10.1016/j.biocontrol.2009.11.011

Fakhro, A., Andrade-Linares, D. R., von Bargen, S., Bandte, M., Büttner, C., Grosch, R., et al. (2010). Impact of Piriformospora indica on tomato growth and on interaction with fungal and viral pathogens. Mycorrhiza 20, 191-200. doi: 10.1007/s00572-009-0279-5

Ferraris, L., Garibaldi, A., and Matta, A. (1974). Polygalacturonase and polygalacturonate trans-eliminase production in vitro and in vivo by Fusarium oxysporum f. sp. lycopersici. J. Phytopathol. 81, 1-14. doi: 10.1111/j.1439-0434.1974.tb02771.x

Fradin, E. F., and Thomma, B. P. (2006). Physiology and molecular aspects of Verticillium wilt diseases caused by $V$. dahliae and V. albo-atrum. Mol. Plant Pathol. 7, 71-86. doi: 10.1111/j.1364-3703.2006.00323.x

França, S. C., Spiessens, K., Pollet, S., Debode, J., De Rooster, L., Callens, D., et al. (2013). Population dynamics of Verticillium species in cauliflower fields: influence of crop rotation, debris removal and ryegrass incorporation. Crop Prot. 54, 134-141. doi: 10.1016/j.cropro.2013.08.008

García, M., Arriagada, C., García-Romera, I., and Ocampo, J. A. (2011). Are plant cell wall hydrolysing enzymes of saprobe fungi implicated in the biological control of the Verticillium dahliae pathogenesis? Crop Prot. 30, 85-87. doi: 10.1016/j.cropro.2010.09.007

Garibaldi, A., Minuto, A., and Gullino, M. L. (2005). Verticillium wilt incited by V. dahliae in Eggplant grafted on Solanum torvum in Italy. Plant Dis. 89, 777-777. doi: 10.1094/pd-89-0777b

Garmendia, I., Aguirreolea, J., and Goicoechea, N. (2006). Defencerelated enzymes in pepper roots during interactions with arbuscular mycorrhizal fungi and/or Verticillium dahliae. Biocontrol 51, 293-310. doi: $10.1007 / \mathrm{s} 10526-005-4238-6$

Garmendia, I., Goicoechea, N., and Aguirreolea, J. (2004a). Antioxidant metabolism in asymptomatic leaves of Verticillium-infected pepper associated with an arbuscular mycorrhizal fungus. J. Phytopathol. 152, 593-599. doi: 10.1111/j.1439-0434.2004.00901.x

Garmendia, I., Goicoechea, N., and Aguirreolea, J. (2004b). Effectiveness of three Glomus species in protecting pepper (Capsicum annuum L.) against Verticillium wilt. Biol. Control 31, 296-305. doi: 10.1016/j.biocontrol.2004.04.015

Garmendia, I., Goicoechea, N., and Aguirreolea, J. (2004c). Plant phenology influences the effect of mycorrhizal fungi on the development of Verticillium-induced wilt in pepper. Eur. J. Plant Pathol. 110, 227-238. doi: 10.1023/B:EJPP.0000019790.45397.90

Geboloǧlu, N., Yanar, Y., Yanar, D., Akyazi, F., and Çakmak, P. (2011). Role of different rootstocks on yield and resistance for Fusarium oxysporium, Verticillium dahliae and Meloidogyne incognita in grafted peppers. Eur. J. Hortic. Sci. 76, 41-44.

Gilardi, G., Garibaldi, A., and Gullino, M. L. (2007). Effect of antagonistic Fusarium spp. and of different commercial biofungicide formulations on Fusarium wilt of lettuce. Phytoparasitica 35, 457-465. doi: 10.1007/BF03020604

Giotis, C., Markelou, E., Theodoropoulou, A., Toufexi, E., Hodson, R., Shotton, P., et al. (2009). Effect of soil amendments and biological control agents (BCAs) on soil-borne root diseases caused by Pyrenochaeta lycopersici and Verticillium albo-atrum in organic greenhouse tomato production systems. Eur. J. Plant Pathol. 123, 387-400. doi: 10.1007/s10658-008-9376-0

Gizi, D., Stringlis, I. A., Tjamos, S. E., and Paplomatas, E. J. (2011). Seedling vaccination by stem injecting a conidial suspension of F2, a non-pathogenic Fusarium oxysporum strain, suppresses Verticillium wilt of eggplant. Biol. Control 58, 387-392. doi: 10.1016/j.biocontrol.2011.06.009

Gkizi, D., Lehmann, S., Haridon, F. L., Serrano, M., and Paplomatas, E. J. (2016). The innate immune signaling system as a regulator of disease resistance and induced systemic resistance activity against Verticillium dahliae. Mol. Plant Microbe Interact. 29, 313-323. doi: 10.1094/MPMI-11-15-0261-R

Gómez-Lama Cabanás, C., Schilirò, E., Valverde-Corredor, A., and Mercado-Blanco, J. (2014). The biocontrol endophytic bacterium Pseudomonas fluorescens PICF7 induces systemic defense responses in 
aerial tissues upon colonization of olive roots. Front. Microbiol. 5:427. doi: $10.3389 /$ fmicb.2014.00427

Gómez-Lama Cabanás, C., Sesmero, R., Valverde-Corredor, A., López-Escudero, F. J., and Mercado-Blanco, J. (2017). A split-root system to assess biocontrol effectiveness and defense-related genetic responses in above-ground tissues during the tripartite interaction Verticillium dahliae-olive-Pseudomonas fluorescens PICF7 in roots. Plant Soil. doi: 10.1007/s11104-017-3269-y. Epub ahead of print].

Grimont, F., and Grimont, P. A. D. (1992). “The genus Serratia," in The Prokaryotes - A Handbook on the Biology of Bacteria: Ecophysiology, Isolation, Identification, Applications, eds A. Balows, H.G. Trüper, M. Dworkin, W. Harder, and K. H. Schleifer (New York, NY: Springer), 2822-2848.

Grogan, R. G., Ioannou, N., Schneider, R. W., Sall, M. A., and Kimble, K. A. (1979). Verticillium wilt on resistant tomato cultivars in California: virulence of isolates from plants and soil and relationship of inoculum density to disease incidence. Phytopathology 69:1176. doi: 10.1094/Phyto-69-1176

Gutteridge, R. J., Jenkyn, J. F., and Bateman, G. L. (2007). The potential of non-pathogenic Gaeumannomyces spp., occurring naturally or introduced into wheat crops or preceding crops, for controlling take-all in wheat. Ann. Appl. Biol. 150, 53-64. doi: 10.1111/j.1744-7348.2006.00107.x

Hall, T. J., Schreiber, L. R., and Leben, C. (1986). Effects of xylemcolonizing Bacillus spp. on Verticillium wilt in Maples. Plant Dis. 70:521. doi: 10.1094/PD-70-521

Han, Q., Wu, F., Wang, X., Qi, H., Shi, L., Ren, A., et al. (2015). The bacterial lipopeptide iturins induce Verticillium dahliae cell death by affecting fungal signalling pathways and mediate plant defence responses involved in pathogenassociated molecular pattern-triggered immunity. Environ. Microbiol. 17, 1166-1188. doi: 10.1111/1462-2920.12538

Heinz, R., Lee, S. W., Saparno, A., Nazar, R. N., and Robb, J. (1998). Cyclical systemic colonization in Verticillium-infected tomato. Physiol. Mol. Plant Pathol. 52, 385-396. doi: 10.1006/pmpp.1998.0163

Herr, L. J. (1995). Biological control of Rhizoctonia solani by binucleate Rhizoctonia spp. and hypovirulent $R$. solani agents. Crop Prot. 14, 179-186. doi: 10.1016/0261-2194(95)00017-G

Hoppenau, C. E., Tran, V., Kusch, H., Aßhauer, K. P., Landesfeind, M., Meinicke, P., et al. (2014). Verticillium dahliae VdTHI4, involved in thiazole biosynthesis, stress response and DNA repair functions, is required for vascular disease induction in tomato. Environ. Exp. Bot. 108, 14-22. doi: 10.1016/j.envexpbot.2013.12.015

Hwang, S. F., Chang, K. F., and Chakravarty, P. (1992). Effects of vesiculararbuscular mycorrhizal fungi on the development of Verticillium and Fusarium Wilts of Alfalfa. Plant Dis. 76:239. doi: 10.1094/PD-76-0239

Inderbitzin, P., and Subbarao, K., V (2014). Verticillium systematics and evolution: how confusion impedes Verticillium wilt management and how to resolve it. Phytopathology 104, 564-574. doi: 10.1094/PHYTO-11-13-0315-IA

Inderbitzin, P., Bostock, R. M., Davis, R. M., Usami, T., Platt, H. W., and Subbarao, K. V. (2011). Phylogenetics and taxonomy of the fungal vascular wilt pathogen Verticillium, with the descriptions of five new species. PLOS ONE 6:e28341. doi: 10.1371/journal.pone.0028341

Johnsson, L., Hökeberg, M., and Gerhardson, B. (1998). Performance of the Pseudomonas chlororaphis biocontrol agent MA 342 against cereal seedborne diseases in field experiments. Eur. J. Plant Pathol. 104, 701-711. doi: 10.1023/A:1008632102747

Kalbe, C., Marten, P., and Berg, G. (1996). Strains of the genus Serratia as beneficial rhizobacteria of oilseed rape with antifungal properties. Microbiol. Res. 151, 433-439. doi: 10.1016/S0944-5013(96)80014-0

Kapulnik, Y., Tsror, L., Zipori, I., Hazanovsky, M., Wininger, S., and Dag, A. (2010). Effect of AMF application on growth, productivity and susceptibility to Verticillium wilt of olives grown under desert conditions. Symbiosis 52, 103-111. doi: 10.1007/s13199-010-0085-Z

Karagiannidis, N., Bletsos, F., and Stavropoulos, N. (2002). Effect of Verticillium wilt (Verticillium dahliae Kleb.) and mycorrhiza (Glomus mosseae) on root colonization, growth and nutrient uptake in tomato and eggplant seedlings. Sci. Hortic. 94, 145-156. doi: 10.1016/S0304-4238(01) 00336-3

Keinath, A. P., and Fravel, D. R. (1992). Induction of soil suppressiveness to Verticillium wilt of potato by successive croppings. Am. Potato J. 69, 503-513. doi: $10.1007 / \mathrm{BF} 02853839$
Keinath, A. P., Fravel, D. R., and Papavizas, G. C. (1991). Potential of Gliocladium roseum for biocontrol of Verticillium dahliae. Phytopathology 81:644. doi: 10.1094/Phyto-81-644

Klimes, A., Dobinson, K. F., Thomma, B. P. H. J., and Klosterman, S. J. (2015). Genomics spurs rapid advances in our understanding of the biology of vascular wilt pathogens in the genus Verticillium. Annu. Rev. Phytopathol. 53, 181-198. doi: 10.1146/annurev-phyto-080614-120224

Klosterman, S. J., Subbarao, K. V., Kang, S., Veronese, P., Gold, S. E., Thomma, B. P. H. J., et al. (2011). Comparative genomics yields insights into niche adaptation of plant vascular wilt pathogens. PLoS Pathog. 7:e1002137. doi: 10.1371/journal.ppat.1002137

Kurze, S., Bahl, H., Dahl, R., and Berg, G. (2001). Biological control of fungal strawberry diseases by Serratia plymuthica HRO-C48. Plant Dis. 85, 529-534. doi: 10.1094/PDIS.2001.85.5.529

Lal, S., and Tabacchioni, S. (2009). Ecology and biotechnological potential of Paenibacillus polymyxa: a minireview. Indian J. Microbiol. 49, 2-10. doi: 10.1007/s12088-009-0008-y

Larena, I., Sabuquillo, P., Melgarejo, P., and De Cal, A. (2003). Biocontrol of Fusarium and Verticillium Wilt of tomato by Penicillium oxalicum under greenhouse and field conditions. J. Phytopathol. 151, 507-512. doi: 10.1046/j.1439-0434.2003.00762.x

Lazarovits, G., and Subbarao, K. (2009). "Challenges in controlling Verticillium Wilt by the use of nonchemical methods," in Recent Developments in Management of Plant Diseases, eds U. Gisi, I. Chet, and M. L. Gullino (Dordrecht: Springer), 247-264.

Leben, S. D., Wadi, J. A., and Easton, G. D. (1987). Effects of Pseudomonas fluorescens on potato plant growth and control of Verticillium dahliae. Phytopathology 77:1592. doi: 10.1094/Phyto-77-1592

Li, C.-H., Shi, L., Han, Q., Hu, H.-L., Zhao, M.-W., Tang, C.-M., et al. (2012). Biocontrol of verticillium wilt and colonization of cotton plants by an endophytic bacterial isolate. J. Appl. Microbiol. 113, 641-651. doi: 10.1111/j.1365-2672.2012.05371.x

Li, C.-H., Zhao, M.-W., Tang, C.-M., and Li, S.-P. (2010). Population dynamics and identification of endophytic bacteria antagonistic toward plant-pathogenic fungi in cotton root. Microb. Ecol. 59, 344-356. doi: 10.1007/s00248-009-9570-4

Li, J.-G., Jiang, Z.-Q., Xu, L.-P., Sun, F.-F., and Guo, J.-H. (2008). Characterization of chitinase secreted by Bacillus cereus strain $\mathrm{CH} 2$ and evaluation of its efficacy against Verticillium wilt of eggplant. BioControl 53, 931-944. doi: 10.1007/s10526-007-9144-7

Li, S., Zhang, N., Zhang, Z., Luo, J., Shen, B., Zhang, R., et al. (2013). Antagonist Bacillus subtilis HJ5 controls Verticillium wilt of cotton by root colonization and biofilm formation. Biol. Fertil. Soils 49, 295-303. doi: 10.1007/s00374-012-0718-x

Li, Z. F., Wang, L. F., Feng, Z. L., Zhao, L. H., Shi, Y. Q., and Zhu, H. Q. (2014). Diversity of endophytic fungi from different Verticilliumwilt-resistant Gossypium hirsutum and evaluation of antifungal activity against Verticillium dahliae in vitro. J. Microbiol. Biotechnol. 24, 1149-1161. doi: 10.4014/jmb.1402.02035

Lin, L., Qiao, Y.-S., Ju, Z.-Y., Ma, C.-W., Liu, Y.-H., Zhou, Y.-J., et al. (2009). Isolation and characterization of endophytic Bacillius subtilis Jaas ed1 antagonist of eggplant Verticillium Wilt. Biosci. Biotechnol. Biochem. 73, 1489-1493. doi: 10.1271/bbb.80812

Liu, R.-J. (1995). Effect of vesicular-arbuscular mycorrhizal fungi on Verticillium wilt of cotton. Mycorrhiza 5, 293-297. doi: 10.1007/BF00204965

Loper, J. E., and Buyer, J. S. (1991). Current Review Siderophores in Microbial Interactions on Plant Surfaces. Mol. Plant Microbe Interact. 4:5. doi: 10.1094/MPMI-4-005

Loper, J. E., and Henkels, M. D. (1999). Utilization of heterologous siderophores enhances levels of iron available to Pseudomonas putida in the rhizosphere. Appl. Environ. Microbiol. 65, 5357-5363.

López-Escudero, F. J., and Mercado-Blanco, J. (2011). Verticillium wilt of olive: a case study to implement an integrated strategy to control a soil-borne pathogen. Plant Soil 344, 1-50. doi: 10.1007/s11104-010-0629-2

Luo, J., Ran, W., Hu, J., Yang, X., Xu, Y., and Shen, Q. (2010). Application of bioorganic fertilizer significantly affected fungal diversity of soils. Soil Sci. Soc. Am. J. 74, 2039-2048. doi: 10.2136/sssaj2009.0437

Malandraki, I., Tjamos, S. E., Pantelides, I. S., and Paplomatas, E. J. (2008). Thermal inactivation of compost suppressiveness implicates possible 
biological factors in disease management. Biol. Control 44, 180-187. doi: 10.1016/j.biocontrol.2007.10.006

Malcolm, G. M., Kuldau, G. A., Gugino, B. K., and Jimenez-Gasco, M. D. (2013). Hidden host plant associations of soilborne fungal pathogens: an ecological perspective. Phytopathology 103, 538-544. doi: 10.1094/PHYTO-08-12-0192-LE

Maldonado-González, M. M., Bakker, P. A., Prieto, P., and Mercado-Blanco, J. (2015a). Arabidopsis thaliana as a tool to identify traits involved in Verticillium dahliae biocontrol by the olive root endophyte Pseudomonas fluorescens PICF7. Front. Microbiol. 6:266. doi: 10.3389/fmicb.2015.00266

Maldonado-González, M. M., Schilirò, E., Prieto, P., and Mercado-Blanco, J. (2015b). Endophytic colonization and biocontrol performance of Pseudomonas fluorescens PICF7 in olive (Olea europaea L.) are determined neither by pyoverdine production nor swimming motility. Environ. Microbiol. 17, 3139-3153. doi: 10.1111/1462-2920.12725

Markakis, E. A., Tjamos, S. E., Antoniou, P. P., Paplomatas, E. J., and Tjamos, E. C. (2016). Biological control of Verticillium wilt of olive by Paenibacillus alvei, strain K165. Biocontrol 61, 293-303. doi: 10.1007/s10526-015-9669-0

Markakis, E. A., Tjamos, S. E., Chatzipavlidis, I., Antoniou, P. P., and Paplomatas, E. J. (2008). Evaluation of compost amendments for control of Vascular Wilt diseases. J. Phytopathol. 156, 622-627. doi: 10.1111/j.1439-0434.2008.01422.x

Marois, J. J., Johnston, S. A., Dunn, M. T., and Papavizas, G. C. (1982). Biological control of Verticillium Wilt of eggplant in the field. Plant Dis. 66, 1166-1168. doi: 10.1094/PD-66-1166

Martinez, F., Flores, F., Vazquez-Ortiz, E., and Lopez-Medina, J. (2009). Persistence of Trichoderma asperellum population in strawberry soilless culture growing systems. Acta Hortic. 842, 1003-1006. doi: 10.17660/ActaHortic.2009.842.223

Massart, S., Perazzolli, M., Höfte, M., Pertot, I., and Jijakli, M. H. (2015). Impact of the omic technologies for understanding the modes of action of biological control agents against plant pathogens. Biocontrol 60, 725-746. doi: $10.1007 / \mathrm{s} 10526-015-9686-\mathrm{Z}$

Matsubara, Y., Tamura, H., and Harada, T. (1995). Growth enhancement and Verticillium Wilt control by vesicular-arbuscular Mycorrhizal fungus inoculation in eggplant. J. Jpn. Soc. Hortic. Sci. 64, 555-561. doi: $10.2503 /$ jjshs. 64.555

Matta, A., and Garibaldi, A. (1977). Control of Verticillium wilt of tomato by preinoculation with avirulent fungi. Neth. J. Plant Pathol. 83, 457-462. doi: 10.1007/BF03041463

Maurhofer, M., Baehler, E., Notz, R., Martinez, V., and Keel, C. (2004). Cross Talk between 2,4-Diacetylphloroglucinol-producing biocontrol Pseudomonads on wheat roots. Appl. Environ. Microbiol. 70, 1990-1998. doi: 10.1128/AEM.70.4.1990-1998.2004

Melouk, H. A., and Horner, C. E. (1975). Cross protection in mints by Verticillium nigrescens against, $V$. dahliae. Phytopathology 65:767. doi: $10.1094 /$ phyto-65-767

Mercado-Blanco, J., Rodriguez-Jurado, D., Hervás, A., and Jiménez-Diaz, R. M. (2004). Suppression of Verticillium wilt in olive planting stocks by root-associated fluorescent Pseudomonas spp. Biol. Control 30, 474-486. doi: 10.1016/j.biocontrol.2004.02.002

Meschke, H., and Schrempf, H. (2010). Streptomyces lividans inhibits the proliferation of the fungus Verticillium dahliae on seeds and roots of Arabidopsis thaliana. Microb. Biotechnol. 3, 428-443. doi: 10.1111/j.1751-7915.2010.00165.x

Meschke, H., Walter, S., and Schrempf, H. (2012). Characterization and localization of prodiginines from Streptomyces lividans suppressing Verticillium dahliae in the absence or presence of Arabidopsis thaliana. Environ. Microbiol. 14, 940-952. doi: 10.1111/j.1462-2920.2011.02665.x

Minuto, A., Spadaro, D., Garibaldi, A., and Gullino, M. L. (2006). Control of soilborne pathogens of tomato using a commercial formulation of Streptomyces griseoviridis and solarization. Crop Prot. 25, 468-475. doi: 10.1016/j.cropro.2005.08.001

Mirmajlessi, S. M., Mänd, M., Najdabbasi, N., Larena, I., and Loit, E. (2016). Screening of native Trichoderma harzianum isolates for their ability to control Verticillium wilt of strawberry. Zemdirbyste 103, 397-404. doi: 10.13080/z-a.2016.103.051

Molina, L., Constantinescu, F., Michel, L., Reimmann, C., Duffy, B., and Défago, G. (2003). Degradation of pathogen quorum-sensing molecules by soil bacteria: a preventive and curative biological control mechanism. FEMS Microbiol. Ecol. 45, 71-81. doi: 10.1016/S0168-6496(03)00125-9

Morello, J. E., Pierson, E. A., and Pierson, L. S. (2004). Negative Cross-communication among wheat rhizosphere bacteria: effect on antibiotic production by the biological control Bacterium Pseudomonas aureofaciens 30-84. Appl. Environ. Microbiol. 70, 3103-3109. doi: 10.1128/AEM.70.5.3103-3109.2004

Müller, H., and Berg, G. (2008). Impact of formulation procedures on the effect of the biocontrol agent Serratia plymuthica HRO-C48 on Verticillium wilt in oilseed rape. BioControl 53, 905-916. doi: 10.1007/s10526-007-9111-3

Nagtzaam, M. P. M., Bollen, G. J., and Termorshuizen, A. J. (1998). Efficacy of Talaromyces flavus alone or in combination with other antagonists in controlling Verticillium dahliae in growth chamber experiments. J. Phytopathol. 146, 165-173. doi: 10.1111/j.1439-0434.1998.tb04674.x

Naraghi, L., Heydari, A., Rezaee, S., Razavi, M., and Afshari-Azad, H. (2010a). Biological control of Verticillium wilt of greenhouse cucumber by Talaromyces flavus. Phytopathol. Mediterr. 49, 321-329. doi: 10.14601/Phytopathol_Mediterr-8450

Naraghi, L., Heydari, A., Rezaee, S., Razavi, M., and Jahanifar, H. (2010b). Study on antagonistic effects of Talaromyces flavus on Verticillium alboatrum, the causal agent of potato wilt disease. Crop Prot. 29, 658-662. doi: 10.1016/j.cropro.2010.01.011

Narisawa, K., Kawamata, H., Currah, R. S., and Hashiba, T. (2002). Suppression of Verticillium wilt in eggplant by some fungal root endophytes. Eur. J. Plant Pathol. 108, 103-109. doi: 10.1023/A:1015080311041

Narisawa, K., Ohki, K. T., and Hashiba, T. (2000). Suppression of clubroot and Verticillium yellows in Chinese cabbage in the field by the root endophytic fungus, Heteroconium chaetospira. Plant Pathol. 49, 141-146. doi: 10.1046/j.1365-3059.2000.00425.x

Narisawa, K., Usuki, F., and Hashiba, T. (2004). Control of Verticillium yellows in Chinese cabbage by the dark septate endophytic fungus LtVB3. Phytopathology 94, 412-418. doi: 10.1094/PHYTO.2004.94.5.412

Ordentlich, A., Nachmias, A., and Chet, I. (1990). Integrated control of Verticillium dahliae in potato by Trichoderma harzianum and captan. Crop Prot. 9, 363-366. doi: 10.1016/0261-2194(90)90008-U

Pantelides, I. S., Tjamos, S. E., Striglis, I. A., Chatzipavlidis, I., and Paplomatas, E. J. (2009). Mode of action of a non-pathogenic Fusarium oxysporum strain against Verticillium dahliae using Real Time QPCR analysis and biomarker transformation. Biol. Control 50, 30-36. doi: 10.1016/j.biocontrol.2009.01.010

Papasotiriou, F. G., Varypatakis, K. G., Christofi, N., Tjamos, S. E., and Paplomatas, E. J. (2013). Olive mill wastes: a source of resistance for plants against Verticillium dahliae and a reservoir of biocontrol agents. Biol. Control 67, 51-60. doi: 10.1016/j.biocontrol.2013.07.008

Pegg, G. F., and Brady, B. L. (2002). Verticillium Wilts. Wallingford: CABI Publishing.

Porras-Soriano, A., Marcilla-Goldaracena, I., Soriano-Martín, M. L., and PorrasPiedra, A. (2006). Development and resistance to Verticillium dahliae of olive plantlets inoculated with mycorrhizal fungi during the nursery period. J. Agric. Sci. 144:151. doi: 10.1017/S0021859606005880

Prieto, P., Navarro-Raya, C., Valverde-Corredor, A., Amyotte, S. G., Dobinson, K. F., and Mercado-Blanco, J. (2009). Colonization process of olive tissues by Verticillium dahliae and its in planta interaction with the biocontrol root endophyte Pseudomonas fluorescens PICF7. Microb. Biotechnol. 2, 499-511. doi: 10.1111/j.1751-7915.2009.00105.x

Puhalla, J. E., and Bell, A. A. (1981). "Genetics and biochemistry of Wilt of pathogens," in Fungal Wilt Diseases of Plants, eds M. E. Mace, A. A. Bell, and C. H. Beckman (New York, NY: Academic Press Inc.), 146-192.

Qin, Q.-M., Vallad, G. E., and Subbarao, K. V. (2008). Characterization of Verticillium dahliae and $V$. tricorpus isolates from lettuce and artichoke. Plant Dis. 92, 69-77. doi: 10.1094/PDIS-92-1-0069

Rekanovic, E., Milijasevic, S., Todorovic, B., and Potocnik, I. (2007). Possibilities of biological and chemical control of Verticillium wilt in pepper. Phytoparasitica 35, 436-441. doi: 10.1007/BF03020601

Robinson, N., Platt, H. W., and Hale, L. R. (2007). Interactions of various Verticillium species in combination with $V$. albo-atrum on Verticillium wilt disease development in potato. Am. J. Potato Res. 84, 133-141. doi: $10.1007 / \mathrm{BF} 02987136$ 
Ruano-Rosa, D., Prieto, P., Rincón, A. M., Gómez-Rodríguez, M. V., Valderrama, R., Barroso, J. B., et al. (2016). Fate of Trichoderma harzianum in the olive rhizosphere: time course of the root colonization process and interaction with the fungal pathogen Verticillium dahliae. Biocontrol 61, 269-282. doi: 10.1007/s10526-015-9706-z

Rybakova, D., Schmuck, M., Wetzlinger, U., Varo-Suarez, A., Murgu, O., Müller, H., et al. (2016). Kill or cure? The interaction between endophytic Paenibacillus and Serratia strains and the host plant is shaped by plant growth conditions. Plant Soil 405, 65-79. doi: 10.1007/s11104-015-2572-8

Sabuquillo, P., De Cal, A., and Melgarejo, P. (2006). Biocontrol of tomato wilt by Penicillium oxalicum formulations in different crop conditions. Biol. Control 37, 256-265. doi: 10.1016/j.biocontrol.2006.02.009

Sabuquillo, P., De Cal, A., and Melgarejo, P. (2005). Dispersal improvement of a powder formulation of Penicillium oxalicum, a biocontrol agent of tomato wilt. Plant Dis. 89, 1317-1323. doi: 10.1094/PD-89-1317

Sant, D., Casanova, E., Segarra, G., Aviles, M., Reis, M., and Trillas, M. I. (2010). Effect of Trichoderma asperellum strain T34 on Fusarium wilt and water usage in carnation grown on compost-based growth medium. Biol. Control 53, 291-296. doi: 10.1016/j.biocontrol.2010.01.012

Schaible, L., Cannon, O., and Waddoups, V. (1951). Inheritance of resistance to Verticillium wilt in a tomato cross. Phytopathology 41, 986-990.

Schilirò, E., Ferrara, M., Nigro, F., and Mercado-Blanco, J. (2012). Genetic responses induced in olive roots upon colonization by the biocontrol endophytic bacterium Pseudomonas fluorescens PICF7. PLoS ONE 7:e48646. doi: 10.1371 /journal.pone. 0048646

Schnathorst, W. C. (1981). "Life Cycle and epidemiology of Verticillium," in Fungal Wilt Diseases of Plants, eds M. E. Mace, A. A. Bell, and C. H. Beckman (New York, NY: Academic Press Inc.), 81-111.

Schnathorst, W. C., and Mathre, D. E. (1966). Cross-protection in cotton with strains of Verticillium albo-atrum. Phytopathology 56, 1204-1209.

Schoina, C., Stringlis, I. A., Pantelides, I. S., Tjamos, S. E., and Paplomatas, E. J. (2011). Evaluation of application methods and biocontrol efficacy of Paenibacillus alvei strain K-165, against the cotton black root rot pathogen Thielaviopsis basicola. Biol. Control 58, 68-73. doi: 10.1016/j.biocontrol.2011.04.002

Schüßler, A., and Walker, C. (2010). The Glomeromycota. A Species List with New Fenera and New Genera. Available online at: http://www.amf-phylogeny.com/

Shittu, H. O., Castroverde, D. C. M., Nazar, R. N., and Robb, J. (2009). Plantendophyte interplay protects tomato against a virulent Verticillium. Planta 229, 415-426. doi: 10.1007/s00425-008-0840-z

Ślusarski, C., and Pietr, S. J. (2009). Combined application of dazomet and Trichoderma asperellum as an efficient alternative to methyl bromide in controlling the soil-borne disease complex of bell pepper. Crop Prot. 28, 668-674. doi: 10.1016/j.cropro.2009.03.016

Solarska, E., Fravel, D. R., and Pietr, S. (2000). "Antagonistic action of Talaromyces flavus and Trichoderma viride against Verticillium albo-atrum on Hops," in Advances in Verticillium Research and Disease Management, eds E. C. Tjamos, R. C. Rowe, J. B. Heale, and D. R. Fravel (St. Paul, MN: APS Press), 237-239.

Stadler, M., and von Tiedemann, A. (2014). Biocontrol potential of Microsphaeropsis ochracea on microsclerotia of Verticillium longisporum in environments differing in microbial complexity. Biocontrol 59, 449-460. doi: $10.1007 /$ s10526-014-9586-7

Stinson, A. M., Zidack, N. K., Strobel, G. A., and Jacobsen, B. J. (2003). Mycofumigation with Muscodor albus and Muscodor roseus for control of seedling diseases of sugar beet and Verticillium Wilt of eggplant. Plant Dis. 87, 1349-1354. doi: 10.1094/PDIS.2003.87.11.1349

Tjamos, E. C., Tsitsigiannis, D. I., Tjamos, S. E., Antoniou, P. P., and Katinakis, P. (2004). Selection and screening of endorhizosphere bacteria from solarized soils as biocontrol agents against Verticillium dahliae of solanaceous hosts. Eur. J. Plant Pathol. 110, 35-44. doi: 10.1023/B:EJPP.0000010132.91241.cb

Tjamos, S. E., Flemetakis, E., Paplomatas, E. J., and Katinakis, P. (2005). Induction of resistance to Verticillium dahliae in Arabidopsis thaliana by the biocontrol agent K-165 and pathogenesis-related proteins gene expression. Mol. Plant. Microbe. Interact. 18, 555-561. doi: 10.1094/MPMI18-0555

Tyvaert, L., França, S. C., Debode, J., and Höfte, M. (2014). The endophyte Verticillium Vt305 protects cauliflower against Verticillium wilt. J. Appl. Microbiol. 116, 1563-1571. doi: 10.1111/jam.12481
Uppal, A. K., El Hadrami, A., Adam, L. R., Tenuta, M., and Daayf, F. (2007). Pathogenic variability of Verticillium dahliae isolates from potato fields in Manitoba and screening of bacteria for their biocontrol. Can. J. Plant Pathol. 29, 141-152. doi: 10.1080/07060660709507450

Uppal, A. K., El Hadrami, A., Adam, L. R., Tenuta, M., and Daayf, F. (2008). Biological control of potato Verticillium wilt under controlled and field conditions using selected bacterial antagonists and plant extracts. Biol. Control 44, 90-100. doi: 10.1016/j.biocontrol.2007.10.020

Vagelas, I., and Leontopoulos, S. (2015). Cross-protection of cotton against Verticillium wilt by Verticillium nigrescens. Emirates J. Food Agric. 27, 1. doi: 10.9755/ejfa.2015-04-047

van Lenteren, J. C., Bolckmans, K., Köhl, J., Ravensberg, W. J., and Urbaneja, A. (2017). Biological control using invertebrates and microorganisms: plenty of new opportunities. BioControl. doi: 10.1007/s10526-017-9801-4. [Epub ahead of print].

Varo, A., Moral, J., Lozano-Tóvar, M. D., and Trapero, A. (2016a). Development and validation of an inoculation method to assess the efficacy of biological treatments against Verticillium wilt in olive trees. Biocontrol 61, 283-292. doi: 10.1007/s10526-015-9710-3

Varo, A., Raya-Ortega, M. C., and Trapero, A. (2016b). Selection and evaluation of micro-organisms for biocontrol of Verticillium dahliae in olive. J. Appl. Microbiol. 121, 767-777. doi: 10.1111/jam.13199

Veloso, J., and Díaz, J. (2012). Fusarium oxysporum Fo47 confers protection to pepper plants against Verticillium dahliae and Phytophthora capsici, and induces the expression of defence genes. Plant Pathol. 61, 281-288. doi: 10.1111/j.1365-3059.2011.02516.x

Veronese, P., Narasimhan, M. L., Stevenson, R. A, Zhu, J.-K., Weller, S. C., Subbarao, K. V., et al. (2003). Identification of a locus controlling Verticillium disease symptom response in Arabidopsis thaliana. Plant J. 35, 574-587. doi: 10.1046/j.1365-313X.2003.01830.x

Weissinger, H., Spornberger, A., and Jezik, K. (2009). Evaluation of new strawberry cultivars and of beneficial microbes to improve strawberry production in Verticillium-Infested soils. Acta Hortic. 828, 133-138. doi: 10.17660/ActaHortic.2009.838.22

Whipps, J. M., and McQuilken, M. P. (2009). "Biological control agents in plant disease control," in Disease Control in Crops - Biological and Environmentally Friendly Approaches, ed D. Walters (Oxford: Wiley-Blackwell), 27-61.

Xue, L., Gu, M. Y., Xu, W. L., Lu, J. J., and Xue, Q. H. (2016). Antagonistic Streptomyces enhances defense-related responses in cotton for biocontrol of wilt caused by phytotoxin of Verticillium dahliae. Phytoparasitica 44, 225-237. doi: 10.1007/s12600-016-0517-2

Xue, L., Xue, Q., Chen, Q., Lin, C., Shen, G., and Zhao, J. (2013). Isolation and evaluation of rhizosphere actinomycetes with potential application for biocontrol of Verticillium wilt of cotton. Crop Prot. 43, 231-240. doi: 10.1016/j.cropro.2012.10.002

Yang, P., Sun, Z. X., Liu, S. Y., Lu, H. X., Zhou, Y., and Sun, M. (2013). Combining antagonistic endophytic bacteria in different growth stages of cotton for control of Verticillium wilt. Crop Prot. 47, 17-23. doi: 10.1016/j.cropro.2012.12.020

Yang, W., Zheng, L., Liu, H.-X., Wang, K.-B., Wang, Y.-P., Luo, Y.-M., et al. (2014). Evaluation of the effectiveness of a consortium of three plant-growth promoting rhizobacteria for biocontrol of cotton Verticillium wilt. Biocontrol Sci. Technol. 24, 489-502. doi: 10.1080/09583157.2013.873389

Yuan, Y., Feng, H., Wang, L., Li, Z., Shi, Y., Zhao, L., et al. (2017). Potential of endophytic fungi isolated from cotton roots for biological control against Verticillium Wilt disease. PLoS ONE 12: e0170557. doi: 10.1371/journal.pone.0170557

Zeise, K., and Kersten, H. (2000). "The Potential of Talaromyces flavus in controlling Verticillium dahliae," in Advances in Verticillium Research and Disease Management, eds E. C. Tjamos, R. C. Rowe, J. B. Heale, and D. R. Fravel (St. Paul, MN: APS Press), 232-236.

Zhang, G., Raza, W., Wang, X., Ran, W., and Shen, Q. (2012). Systemic modification of cotton root exudates induced by arbuscular mycorrhizal fungi and Bacillus vallismortis HJ-5 and their effects on Verticillium wilt disease. Appl. Soil Ecol. 61, 85-91. doi: 10.1016/j.apsoil.2012.02.003

Zhang, H. J., Dong, H. Z., and Li, W. J. (2011). Dead mycelium of Penicillium chrysogenum protects transplanted cotton plants agains fungal wilts in a saline field. Span. J. Agric. Res. 9, 873-881. doi: 10.5424/sjar/20110903525-10 
Zhang, Q., Yang, L., Zhang, J., Wu, M., Chen, W., Jiang, D., et al. (2015). Production of anti-fungal volatiles by non-pathogenic Fusarium oxysporum and its efficacy in suppression of Verticillium wilt of cotton. Plant Soil 392, 101-114. doi: 10.1007/s11104-015-2448-y

Zhang, Y., Fan, T., Jia, W., Zhang, W., Liu, Q., Li, B., et al. (2012). Identification and characterization of a Bacillus subtilis strain TS06 as bio-control agent of strawberry replant disease (Fusarium and Verticillium wilts). Afr. J. Biotechnol. 11, 570-580. doi:10.5897/AJB11.1131

Zheng, Y., Xue, Q. Y., Xu, L. L., Xu, Q., Lu, S., Gu, C., et al. (2011). A screening strategy of fungal biocontrol agents towards Verticillium wilt of cotton. Biol. Control 56, 209-216. doi: 10.1016/j.biocontrol.2010. 11.010

Zhou, L., Hu, Q., Johansson, A., and Dixelius, C. (2006). Verticillium longisporum and $V$. dahliae: infection and disease in Brassica napus. Plant. Pathol. 55, 137-144. doi: 10.1111/j.1365-3059.2005. 01311.x
Zhu, H., Feng, Z., Li, Z., Shi, Y., Zhao, L., and Yang, J. (2013). Characterization of two fungal isolates from cotton and evaluation of their potential for biocontrol of Verticillium wilt of cotton. J. Phytopathol. 161, 70-77. doi: 10.1111/jph.12027 Zipfel, C. (2014). Plant pattern-recognition receptors. Trends Immunol. 35, 345-351. doi: 10.1016/j.it.2014.05.004

Conflict of Interest Statement: The authors declare that the research was conducted in the absence of any commercial or financial relationships that could be construed as a potential conflict of interest.

Copyright (C) 2017 Deketelaere, Tyvaert, França and Höfte. This is an open-access article distributed under the terms of the Creative Commons Attribution License (CC $B Y)$. The use, distribution or reproduction in other forums is permitted, provided the original author(s) or licensor are credited and that the original publication in this journal is cited, in accordance with accepted academic practice. No use, distribution or reproduction is permitted which does not comply with these terms. 